\title{
ABSTRACT CLAUSES AND THE DESCRIPTIVE LIMITS OF ORIGINALISM: EMBRACING LEGAL REALISM
}

\author{
SILVIO R. VINCETI*
}

\begin{abstract}
There seems to be an intuitive distinction between the concrete and abstract clauses of the U.S. Constitution: If concrete clauses-such as Article II's requirement that the U.S. President be at least thirty-five years of age-appear fairly uncontroversial as to their meaning and reference, abstract clauses-such as the Eighth Amendment's prohibition of "cruel and unusual punishments"-show a more vague and debatable content.

In the Article, I argue that the peculiar modality of legal change abstract clauses undergo thwarts a complete understanding of the U.S. Constitution in originalist terms. I take up Dworkin's "moral reading" originalism and Bork's "orthodox" one as two archetypal reconstructions of the Framers' intent in regard to abstract clauses. Despite substantial differences, both a Borkean and Dworkinian originalism share a commitment to a formal understanding of abstract clauses. For different reasons, however, they both fail in providing a sound account of abstract clauses' change over time. If Dworkin's account seems at variance with the rationale of a rigid constitution, a Borkean conception of abstract clauses, although interpretatively sound, appears at odds with reality.

From the failure of the two reconstructions, I deduce several conclusions. First, that the best way to make sense of the abstract clauses' change is to give up any formalist account thereof: Abstract clauses give rise to a plain instance of informal legal change, the reason for that possibly being that formalism is in competition with other human valuesnamely, the desirability of the outcomes. In that abstract clauses do not

* Visiting Scholar, Boston University. Ph.D. Candidate, University of Modena and Reggio Emilia, silvioroberto.vinceti@unimore.it.

A first draft of the Article was discussed in a panel at the Conference "Amending America's Unwritten Constitution," held at the Boston College's Institute of Liberal Arts, May 16-17 (2019). I am grateful to Mitchell Berman, Joshua Braver, Oran Doyle, Frederick Schauer and Ryan C. Williams for the encouraging feedback provided on that occasion, to Richard Albert for the kind invitation, and to Eugenio Vezzosi for his precious review of philosophical passages and critical comments on the paper. I thank Samuel Levine for pointing out to me the convergence between his inquiry into the religious and poetic aspects of the Constitution and some of my considerations. I am most indebted to Gary Lawson, whose acute remarks and thoughtful suggestions have immensely sharpened the focus of my research. Finally, I thank Christopher T. Collum and the editorial team of the Washington University Jurisprudence Review for the excellent editorial support. All errors and infelicities remain my own.
\end{abstract}


comport with formalism, an originalist account thereof is not descriptively accurate.

But if abstract clauses do not abide by formal legal reasoning, the lawyer might wonder how to deal with them-especially, when faced in court. I contend that philosophy of language could hardly be of any help, despite the fact that abstract clauses recall the vagaries in reference "indexicals" bring about in analytic philosophy. Conversely, the employment of disciplines that study human behavior in different normative domains might prove decisive.

If these reflections wound up agreeable, the validity of the insights of American legal realism would be reaffirmed. On the one hand, constitutional law is, to some extent, "legally indeterminate"; on the other, empirical social sciences-not armchair philosophy-are our best ally in addressing the indeterminacy. 


\section{TABLE OF CONTENTS}

INTRODUCTION

I. ARTICLE V AND THE ABSTRACT-CONCRETE CLAUSES DiSTINCTION.331

A. Bork's Originalist Argument.

B. The Abstract Clauses of the Constitution and "Expectations Originalism".

II. THE DWORKINIAN ORIGINALIST.

A. Updating the Abstract-Concrete Clauses Distinction

B. The Sublimation of Intention: The Expensiveness of

Dworkin's Reconstruction

1. The Purpose for a Rigid Constitution

2. Three Auxiliary Hypotheses and Their Expensiveness

C. The Deficiency of the Sublimation and Some Quirks on Agency and Communication .

1. Arresting the Sublimation ....

2. Agency and Communication 
D. The Price of Integrity 356

III. THE BORKEAN ORIGINALIST: ABSTRACT ClAuSES AS CONCRETE ClaUSES

A. The "Same Law New Law" Dilemma

B. A Cramped View on Legal Concepts? 361

IV. A BREACH IN THE FORMAL CONSTITUTION 364

A. Partially Jettisoning Formalism. 364

B. Similarities in the Conflict of Laws

V. EMBRACING LEGAL REALISM.

A. Abstract Clauses as Indexicals. 375

B. The Lawyerly Business 378

CONCLUSION 380 


\section{INTRODUCTION}

Every American citizen is at least vaguely aware of the momentous effects constitutional change can produce in the legal system. It may sound surprising that a formal analysis of constitutional change could leave the jurist in a theoretical predicament. More precisely, that by following the logical argumentation that underlies the legal change of a particular type of constitutional clause, the "loyal" originalist interpreter-whose exclusive concern is the meaning of a particular text (i.e., the United States Constitution) - would be compelled to a foregone conclusion: that it is impossible to account for what happens in the legal world if the area of research is restricted to the formal rules set out by the legitimate authority. ${ }^{1}$ An outcome, as we will see, that would bear out one of the fundamental tenets of American legal realism. ${ }^{2}$

Indeed, two classic accounts of the United States Constitution-Robert Bork's "orthodox" originalism and Ronald Dworkin's "moral reading" originalism-seem unable to account for the legal change of the Constitution's "abstract clauses," whose working example in this Article is going to be the Eighth Amendment's prohibition against "cruel and unusual punishments." 3 I argue that, from the failure of these reconstructions, originalism cannot be deemed to fully account for constitutional practice. ${ }^{4}$ That is, if the Baudean question "Is originalism our law?"5 can be answered in the affirmative for the majority of constitutional law, at least in regard to abstract clauses the law is ultimately nonoriginalist. ${ }^{6}$

1. The concept of "law," i.e., as progressively conceived in the positivist tradition from Austin and Hart to Raz and Green. See generally Andrei Marmor \& Alexander Sarch, The Nature of Law, StAN. ENCYClOPEDIA PHIL. (Edward N. Zalta, ed., rev. ed. 2019), https://plato.stanford.edu/archives/fall2019/entries/lawphil-nature/ [https://perma.cc/85RH-P4L5] (summarizing the shibboleths of legal positivism).

2. The idea, i.e., of legal indeterminacy. See infra Part V.B. It might be worth emphasizing that the thesis is "truly realist" insofar as legal indeterminacy, as will see, results from the functioning of legal norms, and not, that is, from the broader problem of the "open-ended" status of the language. See BRIAN LEITER, Rethinking Legal Realism: Toward a Naturalized Jurisprudence, 76 TEXAS L. REV. 267 (1997), reprinted in BRIAN LEITER, NATURALIZING JURISPRUDENCE: ESSAYS ON AMERICAN Legal Realism and Naturalism in Legal Philosophy 1, 27 (2007) [hereinafter Leiter, NATURALIZING JURISPRUDENCE] (contesting C.L.S. writers' portrait of realism as inferring legal indeterminacy from the general nature of the language, rather than from essentially legal problems, e.g., alternative methods of legal interpretation or precedents' selection).

3. "Excessive bail shall not be required, nor excessive fines imposed, nor cruel and unusual punishments inflicted." U.S CONST. amend. VIII.

4. See infra Part IV.A.

5. See William Baude, Is Originalism Our Law?, 115 COLUM. L. REV. 2349 (2015).

6. See infra Part IV.A. 
These alleged limits of originalism's descriptive power do not descend from some possibly true but less interesting facts, such as, for example, that judges make mistakes or misinterpret constitutional clauses in order to impose their moral views. ${ }^{7}$ After all, if we stretch the descriptive attitude of originalism, we might say that by accommodating these phenomena under the label of "improper practices," an originalist model does account for them. On the contrary, as we will see, originalism collapses when it fails to qualify the legal change of abstract clauses either as legitimate or illegitimate, since the procedure it would mandate for their legal change has never been pursued nor has it been taken into consideration. ${ }^{8}$

In Part I of the Article, I introduce Bork's argument for originalism and Dworkin's notion of abstract clauses. In Part II, I expound on why Dworkin's theory is hardly tenable in regard to abstract clauses: In fact, his originalist explanation of the functioning of abstract clauses seems to turn out both "expensive" and "deficient." In Part III, I develop a thought experiment - the "same law, new law" dilemma — which should cast doubt on the capacity of the "traditional" Borkean model to account for the referential change entailed in abstract clauses. ${ }^{9}$ In Part IV, I advocate the subsumption of this type of legal change into the conceptual framework of "informal constitutional change." 10 To depict my understanding of the nexus that hitches abstract clauses to other normative domains, I will resort to a fictional story inspired by the conflict of laws. Finally, in Part $\mathrm{V}$, I confront the possibility of a linguistic treatment of abstract clauses, which seem to match the phenomenology of those expressions analytic philosophy dubs as "indexicals." 11 Disputing the utility of a "linguistic turn" in the understanding of abstract clauses, I contend that the legal

7. "It is true, of course, that if judges are not rational, honest, or competent, or if they make mistakes, then the Class will be Causally Indeterminate, but this is plainly a less interesting point about the law." BRIAN LEITER, A Note on Legal Indeterminacy, in LEITER, NATURALIZING JURISPRUDENCE, supra note 2, at 10-11.

8. See infra Part III-IV.

9. If Dworkin might be credited with raising the problem of abstract clauses, Bork never confronted the issue directly: He merely built an argument in favor of originalism out of the existence of the amendment procedure in the U.S. Constitution. See infra Part I.A. Hence the use of "Borkean" instead of "Bork's." See infra Part III.A.

10. For other examples of informal constitutional change see, for example, Richard Albert, How Unwritten Constitutional Norms Change Written Constitutions, 38 DubliN U. L.J. 387 (2015) (distinguishing between different types of informal constitutional change); Stephen M. Griffin, Against Historical Practice: Facing up to the Challenge of Informal Constitutional Change, 35 CONST. COMMENT. 79 (2020) (discussing the informal nature of constitutional practice).

11. "The term indexicality was coined by the American philosopher Charles Sanders Peirce (1839-1914) to denote a particular kind of semiotic 'ground."' Constantine V. Nakassis, Indexicality's Ambivalent Ground, 6 SIGNS \& SOC'Y 281, 282 (2018). In the present article, however, the only relevant meaning of "indexicals" is the one of Anglo-American philosophy of language. See infra Part V.A. 
change they entail can be addressed only through the type of inquiry suggested by American legal realism.

Should the argument prove tenable, the bearing of the realists' theses on constitutional law should be clearly reaffirmed. The inability of originalism to account for the referential change of abstract clauses is used to emphasize the necessity of the realist approach to constitutional lawthus amending its "original" confinement to other fields of the law. ${ }^{12}$ Certainly, there have already been numerous attempts to conjoin "realism" and constitutional law, ${ }^{13}$ just as the core work of political scientists can be framed as the inadvertent product of some realist research agenda in constitutional law. ${ }^{14}$ In both cases, however, some fundamental tenets of the realist jurisprudence might go missing.

On the one hand, the expression "constitutional realism" is ambiguous and insufficient. It is ambiguous insofar as it can be used to describe the study of constitutional law from the perspective of "moral realism," which

12. Possibly as a consequence of their real lawyerly experience, American realists were mainly focused on issues arising from ordinary civil litigation rather than from the speculative problems of constitutional adjudication. As Brian Leiter notes, "[t]he Realists tend to draw their best examples . . . from the realm of commercial law . . . rather, say, than constitutional law . . .." LEITER, NATURALizing Jurisprudence, supra note 2, at 27. See, e.g., Jerome FranK, LAW AND the MODERN MIND 46-52 (Anchor Book 1963) (discussing the fictional example of the incorporation of a Taxi Company).

13. See, e.g., Matthew S.R. Palmer, Using Constitutional Realism to Identify the Complete Constitution: Lessons from an Unwritten Constitution, 54 AM. J. COMP. L. 587, 627-35 (2006) (arguing, from a study of New Zealand's Unwritten Constitution, the importance of constitutional conventions to recognize the U.S. "complete Constitution"); Connie S. Rosati, Constitutional Realism, in Dimensions of NoRMativity: New EsSAYs ON METAETHICS AND JURISPRUdENCE 393, 396, 411 (David Plunkett, Scott J. Shapiro \& Kevin Toh eds., 2019) (arguing for the existence of true constitutional facts in a metaethical sense).

14. As Brian Leiter writes-concurring in some remark from Frederick Schauer- " politicalscience work on courts is a useful corrective to much doctrinal scholarship in constitutional law, which talks as though the doctrine is really explanatory of Supreme Court decisions." Brian Leiter, Legal Formalism and Legal Realism: What Is The Issue?, 16 LEGAL THEORY 111, 113 n.11 (2010) [hereinafter Leiter, Legal Formalism]. It bears noting that Leiter is neither weighing the quality of "political-science work," nor claiming that political science is the discipline supposed to bring to light the non-legal determinants of Supreme Court decisions. I will be exploring, and criticizing, these possible claims. For typical examples of political science scholarship on constitutional adjudication see, e.g., Robert Dahl, Decision-Making in a Democracy: The Supreme Court as a National PolicyMaker, 6 J. PUB. L. 279, 293 (1957) (arguing that Supreme Court's policy-making - besides temporary moments of disagreements - does eventually conform with the currently dominant "alliance," i.e., the actual majority's political ideas); Lawrence Baum, The Supreme Court in American Politics, 6 ANN. REV. POL. SCI. 161, 171-73 (2003) (discussing the role of the Supreme Court in American law and arguing against an understatement of the efficacy of its decisions); more recently, Ran Hirschl, The Judicialization of Politics, in THE OXFord HANDBOoK of Political ScIENCE 253, 271 (Robert E. Goodin ed., 2011) (arguing that judicial activism arises out of an institutional environment that calls for judicial intervention rather than out of the independent infringement of the judiciary on the political domain). 
has very little to do with American legal realism. ${ }^{15}$ Perhaps more importantly, the term is insufficient at times, as it is employed to (exclusively) describe those instances where judges fall short of applying clear legal rules, either because they are mistaken or, more frequently, because they have some vested interest that elicit the misuse of the law (e.g., they smuggle the enforcement of political moral views as the application of preexistent constitutional rules).$^{16}$ Legal realism, however, is not merely a remedy for human fallibility or the deviant behavior of judges: It allegedly arises from the nature of legal rules, which are sometimes indeterminate-viz., the cases that are in fact litigated. ${ }^{17}$ As the analysis of the Cruel and Unusual Punishments Clause in this Article demonstrates, abstract clauses are inherently "legally indeterminate" because there is unanimous consensus (even by political originalists!) that it should not be applied originalistically. ${ }^{18}$

The difference is stark. In a possible world where the issue of fallacious or malignant judges were to be solved, the "minor realist account" of the law - that is, the one that attributes legal deviations to judicial errors or political abuse of the law-would match the "correct" scenario as conceived, namely, by originalists. American legal realism, instead,

15. As the most prominent advocate of "constitutionalism realism" candidly acknowledges. See Rosati, supra note 13, at 411 (recognizing the incompatibility with American legal realism). See also Michael W. McConnell, A Moral Realist Defense of Constitutional Democracy, 64 CHI.-KENT L. REV. 89 (1988) (contesting Barber's alleged incompatibility of natural right and constitutional democracy).

16. See, e.g., Eric J. Segall, Originalism Off The Ground: A Response To Professors Baude And Sachs, 34 CONST. COMMENT. 313, 313-14, 323-36 (2019) (conflating legal realism with political science's belief that the judges' political values are the determinants of constitutional adjudication); Robert N. Clinton, Original Understanding, Legal Realism, And The Interpretation Of "This Constitution," 72 IOWA L. REV. 1177, 1242, 1260-61 (1987) (describing instrumentalism and realism as the judicial philosophy of the Warren Court and interpreting the realists' constitutional scholarship as an attempt to unveil the conservative biases of the New Deal Court); Richard Ekins \& Graham Gee, Miller, Constitutional Realism and the Politics of Brexit, in THE UK CONSTITUTION AfTER MiLler: BREXIT AND BEYOND 249 (Mark Elliott, Jack Williams \& Allison Young eds., 2018) (using the expression "constitutional realism" to describe the "optimal constitutional practice" from a political standpoint). Of course, there are also comprehensive, non-"politically reductive" accounts of realism in constitutional scholarship. See, e.g., Karl S. Coplan, Legal Realism, Innate Morality, And The Structural Role Of The Supreme Court In The U.S. Constitutional Democracy, 86 TUL. L. REV. 181, 185-95 (2011) (emphasizing the role of legal indeterminacy in realist jurisprudence); Vicki C. Jackson, Comparative Constitutional Law, Legal Realism, and Empirical Legal Science, 96 B.U. L. REV. 1359, 1369-71 (2016) (stressing the employment of other social sciences as one of the central "realist teachings" for constitutional law).

17. See Leiter, NATURALIZING JuRisprudenCe, supra note 2, at 19-20 (exposing C.L.S. writers' account of the realists as supporters of general indeterminacy-i.e., of the thesis that the law is always indeterminate: "To the contrary, Realists were mainly concerned to point out the indeterminacy that exists in those cases that are actually litigated, especially those that make it to the stage of appellate review - a far smaller class of legal cases, and one where indeterminacy in law is far less surprising").

18. See infra Part III. 
alleges that even in that world legal rules would not be, at times, causally explanatory of judicial decisions. ${ }^{19}$ It is not the case that clear legal outcomes are neglected simply because judges want to enforce some personal view: Sometimes the outcome is dictated by the very nature of the law. ${ }^{20}$

On the other hand, I resist the possibility that the problems arising from constitutional law's natural indeterminacy should be handed over to other social sciences. For one, political science scholarship about "realism in adjudication" often boils down to the minor thesis that deviations from originalist interpretation of the Constitution descend from the hidden "political" interests behind adjudication (e.g., strictly partisan biases, economic worldviews, religious commitments, etc. $)^{21}$ In this respect, political scientists share in the insufficiency of "constitutional realism."22

Additionally, another fundamental idea of American legal realism would be "lost in translation" if other sciences were exclusively competent on the matter: the conception of legal scholarship as a "tool for lawyers" (i.e., a research activity that help lawyers win cases by deconstructing the extralegal rules that govern adjudication). ${ }^{23}$ In American legal realism, the rationale for legal scholarship is to predict adjudication and thereby enhance lawyers' ability to win cases. ${ }^{24}$ Other disciplines, conversely, might rightfully be less sensitive to this point of view. ${ }^{25}$ Therefore, I argue

19. "[T] the judge's decision." LEITER, NATURALIZING JURISPRUDENCE, supra note 2, at 9.

20. The fact that the illegality of the outcome does not come from some judicial failing but is mandated by the "nature of the law" is what makes the case of abstract clauses ultimately "interesting." See id. at 9-10.

21. See, e.g., LeE EPstein \& JACK Knight, The Choices Justices MAKe 11, 185-86 (1998) (proposing a strategic model of Supreme Court adjudication where judge exclusively act to enforce personal ideological commitments, thus excluding mere obedience to the law); Hirschl, supra note 14, at 263-64 (reducing the causal role of constitutional catalogs of rights in prompting judicial activism to the enhancement of the "public's rights awareness" and not to the very nature of those rights); James L. Gibson \& Gregory A. Caldeira, Has Legal Realism Damaged the Legitimacy of the U.S. Supreme Court?, 45 LAW \& SOC'Y REV. 195, 195-96, 214 (2011) (interpreting legal realism as the mere unveiling of ideological and political determinants and arguing that "American people understand judicial decisionmaking [sic] in realistic terms.... and they do so under the belief that judges exercise their discretion in a principled and sincere fashion"). Contra Frank B. Cross, The Justices of Strategy, 48 DUKE L.J. 511 (1998) (making a compelling case against political reductionism). See also Gary Lawson, Reflections of an Empirical Reader (Or: Could Fleming Be Right This Time?), 96 B.U. L. REV. 1457, 1473 (2016) (criticizing Whittington's political interpretation of the rise of the "new originalism").

22. See infra Part V.B.

23. See infra Part V.B (interpreting the realists as unaware forerunners of a naturalist and pragmatic approach to the law where the main object was to prophesize judicial decisions).

24. See infra Part V.B.

25. Political science, for example, seems less concerned with the lawyer's point of view than with public policy perspective. See, e.g., Hirschl, supra note 14, at 273. 
that the legal inquiry has a specific and privileged point of view on the issue of legal indeterminacy.

Having delineated the way in which the analysis reconsiders legal realism in constitutional law, three important caveats remain. First, the Borkean and Dworkinian antagonistic accounts are assumed as two "archetypes" 26 for numerous originalist accounts of constitutional amending. However, these two models cannot faithfully exhaust the tapestry of originalist approaches. Any conclusion concerning these accounts should be subjected to the entire range of originalist reconstructions before legitimately claiming that it applies to originalism tout court. ${ }^{27}$

However, a simple observation should lessen the perils of this evidential reduction. The two accounts are held here as descriptive, valuefree theories ${ }^{28}$ - that is, they are assumed to be sincere descriptions of how the Constitution and the constitutional order were conceived to unfold by the Framers. ${ }^{29}$ (I do not address the question of whether this was Bork's

26. I owe Gary Lawson for suggesting the very useful term "archetype."

27. The Eighth Amendment, e.g., the Borkean account should roughly approximate Justice Scalia's more famous one. See, e.g., Harmelin v. Michigan, 501 U.S. 957, 961-96 (1991) (Scalia, J.); Atkins v. Virginia, 122 S.Ct. 2242, 2259-68 (2002) (Scalia, J., dissenting). This Article falls short of considering John Stinneford's recent, but eminently relevant originalist contribution to the interpretation of the Cruel and Unusual Punishments Clause. Stinneford's account differs from Scalia's and Bork's insofar as he deems the Eighth Amendment notion of "unusual" to mean "contrary to long usage" or "contrary to the long standing traditions of common law." John F. Stinneford, The Original Meaning of Unusual: The Eighth Amendment as a Bar to Cruel Innovation, 102 Nw. U. L. REV. 1739, 1745 (2008). Instead of a rule, the Framers embedded in the Constitution a device that would have yielded new applications as time passed. Since my main concern here is the limits of formal constitutional amending - i.e., not the Eighth Amendment per se-I do not address Stinneford's position, which seems essentially concerned with the Cruel and Unusual Punishments Clause. However, his interpretation remains crucial for if it were to be right-and if the problems of the amendment of abstract clauses did not apply to constitutional provisions other than the Eighth Amendment's ban on "cruel and unusual punishments"- the entire issue would be brought to a close.

28. I use "value free" as the literary English translation for Weber's expression "wertfrei." See, e.g., Wilhelm Hennis, The Meaning of 'Wertfreiheit': On the Background and Motives of Max Weber's "Postulate," 12 SOC. THEORY 113 (1994).

29. This is the "semantic" branch of originalism. See Lawrence B. Solum, We Are All Originalists Now, in Robert W. BennetT, LAWrenCe B. Solum, Constitutional ORiginalism 1, 11-12 (2011) (expounding the distinction between normative and semantic originalism). As the difference with "political originalism" will come up several times in the text, I imagine a preliminary explanation might come in handy. The "semantic" (or "descriptive") version of originalism is merely an interpretative enterprise, like the one described by Lawson and Seidman ("Our concern ... is solely with the task of understanding, or expounding, the instruction manual that is the federal Constitution. We aim to describe the appropriate way to read and understand the instructions contained in the Constitution. We have nothing to say about whether any particular people, most notably public officials who carry firearms or command people who carry firearms, should try to follow the instructions in the Constitution once they are understood. That is a substantial question of political morality, not of interpretative theory, and we are not political moralists"). Gary Lawson \& Guy Seidman, Originalism as a Legal Enterprise, 23 Const. Comment. 47, 53 (2006). Conversely, "normative" (or "political") originalism amounts to a prescriptive claim about how constitutional 
and Dworkin's intent or, more likely, if they were simply calling upon the Supreme Court to do better adjudication. $)^{30}$ Through this potential distortion, the two accounts should cover much of contemporary constitutional debate. If Dworkin's approach, for example, might be read as the "descriptive account" within Fleming's recent defense of constitutional "moral reading" 31 or the "new new originalism's" emphasis on the "high level of generality" of abstract clauses, ${ }^{32}$ a descriptive Borkean account should agree with Gary Lawson's "empirical reading" of the Constitution. ${ }^{33}$ In this respect, it is striking to see how any "new" proposal for constitutional adjudication tends to boil down to the particular role abstract clauses play in constitutional interpretation. ${ }^{34}$

Secondly, this research falls into place as a "case study": The Eighth Amendment's Cruel and Unusual Punishments Clause is considered an example for the entire genre of abstract clauses. However, the Fifth Amendment's Due Process Clause, the Fourteenth Amendment's Equal Protection Clause, or the First Amendment's Freedom of Speech Clause could have filled the role. ${ }^{35}$ In choosing to analyze the Cruel and Unusual

adjudication should be carried out by officials and citizens - namely, the claim that they should always defer to the original meaning of the Constitution. See Mitchell N. Berman, Originalism is Bunk, 84 N.Y.U. L. REV. 1, 17-20 (2009) (holding this normative stance to be originalism's central case).

30. As for Dworkin, it ought to be noted, this would simply mean acknowledging the morality entailed in every possible adjudication, not really changing the adjudicative approach. See RONALD DWORKIN, LAW'S EMPIRE 225 (1986) [hereinafter DWORKIN, LAW's EMPIRE].

31. See JAMES E. Fleming, Fidelity To Our IMPERfECt CONSTITUTION 73-97 (2015) (proposing an interpretation of the Constitution as a catalog of "conceptions," i.e., abstract moral principles that should be differently understood over time and charging originalism with authoritarianism).

32. See Peter J. Smith, How Different are Originalism and Non-Originalism?, 62 HASTINGS L.J. 707, 718 (2011) ("The new new originalists' claim that some provisions of the Constitution ought to be interpreted at a high level of generality ....").

33. That is, an account of the constitutional order (merely) as envisaged in the original meaning of the Constitution, albeit actualized, in the sense that it comprises of all the objects that the "criteria for determining the referents" might allow. Cf. Lawson, supra note 21, at 1471 (describing the "empirical reader" as the interpreter whose exclusive interest is the ascertainment of the "criteria for determining the referents of the concepts employed by the hypothetical reader [of the Constitution]"). See infra Part III.B.

34. See, e.g., Adrian Vermeule, Beyond Originalism, The Atlantic (Mar. 31, 2020), https://www.theatlantic.com/ideas/archive/2020/03/common-good-constitutionalism/609037/

[https://perma.cc/BLQ9-L986] (contending that the "majestic generalities and ambiguities of the written Constitution" allow for a "substantive moral reading" inspired to the "common good").

35. Dworkin explicitly regarded these clauses as other instances that occasioned the "moral reading" of the Constitution. See RONALD DWORKIn, FREEDOM'S LAW: THE MORAL READING OF THE AMERICAN CONSTITUTION 2, 7, 12 (1996) [hereinafter Dworkin, FrEedom's LAw]. 
Punishments Clause, I simply followed in Dworkin's ${ }^{36}$ and other scholars' footsteps. $^{37}$

In the third place, this Article holds "originalism" to be roughly coextensive with the jurisprudential concept of "formalism." 38 That is, if possible, even a bolder and riskier move. ${ }^{39}$ Originalism and formalism remain controversial concepts: Confusion about originalism becomes less of a problem when compared with the entanglement over legal formalism, which at times seems to turn murkier the more it is clarified. ${ }^{40}$

As Frederick Schauer illustrates, there seems to be at least consensus that "formalism" entails: a) the idea of "decisionmaking [sic] according to rule" and b) the "screening off from a decisionmaker [of] factors that a sensitive decisionmaker would otherwise take into account." ${ }^{41}$ Following Brian Leiter's straightforward epistemology, originalism relates to formalism as one of the several methods through which the legitimate sources of law ought to be legitimately interpreted. ${ }^{42}$ In this respect, formalism is more properly understood in juxtaposition with legal realism: Where the former affirms the determinacy of legal reasons and their weight in orientating adjudication, the latter contends that legal reasons are not able to determine one outcome in all instances. ${ }^{43}$ In these "deviant cases," judges primarily respond to the "stimulus of the fact" 44 and only then justify the "decision at first sight" with post hoc legal rationalizations. $^{45}$

36. Ronald Dworkin, The Arduous Virtue of Fidelity: Originalism, Scalia, Tribe, and Nerve, 65 FordHAm L. REV. 1249 (1997) [hereinafter Dworkin, The Arduous Virtue].

37. See, e.g., Aileen Kavanagh, Original Intention, Enacted Text, and Constitutional Interpretation, 47 AM. J. JURIS. 255, 265 (2002) (resorting to the Cruel and Unusual Punishments Clause as the subject of scrutiny).

38. For a different, albeit intertwined, meaning of the word "formalism" in constitutional law, see Gary Lawson, Territorial Governments and the Limits of Formalism, 78 CAL. L. REV. 853, 859-60 (1990) ("Formalism, at least in my hands, is an application of originalist textualism to questions of constitutional structure").

39. Although surely frequent in legal literature. See, e.g., Erwin Chemerinsky, Getting Beyond Formalism in Constitutional Law: Constitutional Theory Matters, 54 OKL. L. REV. 1, 4 (2001); Lael K. Weis, What Comparativism Tells Us About Originalism, 11 INT. J. CON. L. 842, 852 (2013); Stephanos Bibas, Justice Scalia's Originalism and Formalism: The Rule of Criminal Law as a Law of Rules, in THE LEGACY OF JUSTiCE ANTONIN SCALIA: REMEMBERING A CONSERVATIVE LEGAL TITAN'S IMPACT ON THE LAW 5 (Elizabeth H. Slattery ed., 2016).

40. See, e.g., Richard A. Posner, Legal Formalism, Legal Realism, and the Interpretation of Statutes and the Constitution, 37 CASE W. RES. L. REV. 179, 181 (1986) (excluding, quite surprisingly, the possibility of a formalist interpretation of statutes and constitutions).

41. Frederick Schauer, Formalism, 97 YALE L.J. 509, 510 (1988).

42. LEITER, NATURALIZING JURISPRUDENCE, supra note 2, at 9.

43. Id. at $23-24$.

44. Id. at 37 .

45. Id. See also FRANK, supra note 12, at 23-34. 
Is it legitimate, then, to conflate originalism with formalism? To a certain extent, it is unavoidable: An originalist application of the law would generally be regarded as formalistic in nature. ${ }^{46}$ The converse, however, might not be similarly correct. Formalism is better understood as an evaluation of the whole class of legal sources, whereas originalism is concerned only with legal texts (mainly, though not exclusively, regarding the U.S. Constitution). ${ }^{47}$ In this respect, originalism boils down to a necessary ingredient of formalism but is not coextensive with it. ${ }^{48}$

It is striking to see, however, that criticisms of formalism and originalism are often indistinguishable. Both legal positions are rejected as flawed interpretative tools or because of their political myopia. ${ }^{49}$ Similarly,

46. See, e.g., Daniel A. Farber, Ages of American Formalism, 90 Nw. U. L. REV. 89, 91 (1995) ("Formalists believe that certainty, stability, and logic are the primary values to be sought by judges .... To implement these values, they embrace formalist methods, such as textualism as a system for interpreting statutes, adherence to established doctrine in common-law cases, and originalism as a method of constitutional interpretation."); Erwin Chemerinsky, Getting beyond Formalism in Constitutional Law: Constitutional Theory Matters, 54 OKLA. L. ReV. 1 (2001) (considering originalism as paradigmatic instance of formalism); Andre LeDuc, Competing Accounts of Interpretation and Practical Reasoning in the Debate over Originalism, 16 U.N.H. L. REV. 51, 93 (2017) ("Originalism offers a formalistic account of constitutional reasoning."). Contra Stephanos Bibas, Originalism and Formalism in Criminal Procedure: The Triumph of Justice Scalia, the Unlikely Friend of Criminal Defendants, 94 GEO. L.J. 183, (2005) (juxtaposing formalism and originalism).

47. As for statutory law, there is a marked preference for speaking of "textualism" and "intentionalism," instead of "originalism." See Frank H. Easterbrook, The Role of Original Intent in Statutory Construction, 11 HARV. J.L \& PUBL. POL'Y 59, 59 (1988) ("For constitutional interpretation, a debate rages among originalists who look to history and intent; structuralists who look to the problems at hand and the structure of the document; nonoriginalists who look to "values" implicit in the document and say that anything achieving more of an identified value is permissible .... For statutes, however, there is no similar debate.").

On the contrary, it is unlikely to come across an "originalist application of common law," although it is perfectly normal to speak about a formalist interpretation thereof. Examples from contract law, either for or against formalism, are sufficiently revealing. See, e.g., CHRISTOPHER C. LANGDELL, A SUMMARY OF THE LAW OF CONTRACTS 1-23 (2d ed. 1880) (expounding common law's offer and acceptance rules); Karl N. Llewellyn, What Price Contract? - An Essay in Perspective, 48 YALE L.J. 15-16 (1931) (undermining rules' ability to dictate only one outcome-e.g., did the carpenter who did not reply to an offer implicitly accept it as she began fabricating the good?).

It seems as though the place of precedents and common law in the originalist debate is restricted to the stress stare decisis might exert on constitutional originalism. See, e.g., Gary Lawson, The Constitutional Case Against Precedent, 17 Harv. J.L. \& PuB. Pol'Y 23 (1994); Richard H. Fallon, Stare Decisis and the Constitution: An Essay on Constitutional Methodology, 76 N.Y.U. L. REV. 570 (2001).

48. This is also why Leiter considers originalism one of the "legitimate methods of interpreting the sources of law." LEITER, NATURALIZING JURISPRUDENCE, supra note 2, at 9.

49. Paul Brest's rejection of "moderate originalism" is still an enduring example of clarity and intellectual honesty. See Paul Brest, The Misconceived Quest for Original Understanding, 60 B.U. L. REV. 204, 224-38 (1980). He first lays out a critique of forms of originalism that seem to be interpretatively unworkable. Id. at 223-24. Then, he admits the paramount need for a constitutional interpretation that agrees with certain Supreme Court's precedents. If an originalist construction of the Constitution does not comport with those rulings (and, implicitly, with the "ends of constitutionalism"), then U.S. citizens are better off with another interpretative method he calls "mere adjudication." "[A]djudication which takes account of the text and original understanding without, 


\section{it is hard to find proponents of originalism that do not adhere at least to some level of formalism. ${ }^{50}$}

One possible reason for the conflation of the two concepts is that they are often presented as though they share a common normative goal. Allegedly, both originalism and formalism aim at constraining the judge's lawmaking appetite by cultivating the idea of the judiciary as some sort of "null power." 51 This is evidently true of the Borkean originalism, but it

however, treating them as authoritative, generally serves the ends of constitutionalism better than originalist interpretation." Id. at 224. The choice between originalism and nonoriginalism should rest on a pragmatic answer to the following question: "How well, compared to possible alternatives, does the practice contribute to the well-being of our society-or, more narrowly, to the ends of constitutional government?" Id. at 226.

Political criticism of originalist adjudication is perhaps more straightforward in politics. For example, consider Hon. Dianne Feinstein's opening statement in Neil Gorsuch's Supreme Court confirmation hearing:

Judge Gorsuch has also stated that he believes judges should look to the original public meaning of the Constitution when they decide what a provision of the Constitution means. This is personal, but I find this originalist judicial philosophy to be really troubling. In essence, it means the judges and courts should evaluate our constitutional rights and privileges as they were understood in 1789 . However, to do so would not only ignore the intent of the Framers that the Constitution would be a framework on which to build, but it severely limits the genius of what our Constitution upholds. . . In fact, if we were to dogmatically adhere to originalist interpretations, then we would still have segregated schools and bans on interracial marriage. Women would not be entitled to equal protection under the law, and government discrimination against LGBT Americans would be permitted. So I am concerned when I hear that Judge Gorsuch is an originalist and a strict constructionist.

The Nomination of Hon. Neil M. Gorsuch to Be an Associate Justice of the Supreme Court of the United States: Confirmation Hearing Before S. Comm. on the Judiciary, 115th Cong. 8-9 (2018) (Opening Statement of Sen. Dianne Feinstein, Member Sen. Comm. on the Judiciary).

Against formalism, there had been many critiques on the grounds of the bad policy results it might give rise to. Generally, they were framed out of some natural law theory. This is implicit, e.g., in the widely known Formula of Gustav Radbruch, who regarded positivism to be roughly identical to what we ordinarily call "formalism" ("The conflict between justice and legal certainty may well be resolved in this way: The positive law, secured by legislation and power, takes precedence even when its content is unjust and fails to benefit the people, unless the conflict between statute and justice reaches such an intolerable degree that the statute, as 'flawed law', must yield to justice"). Gustav Radbruch, Statutory Lawlessness and Supra-Statutory Law, 26 OXFORD J. LEGAL ST. 1, 7 (Bonnie Litschewski Paulson \& Stanley L. Paulson, trans., 2006).

50. Justice Antonin Scalia, e.g., held textualism to be coextensive with originalism and crisply captured the overlapping criticism toward formalism and originalism: "Of all the criticisms leveled against textualism, the most mindless is that it is 'formalistic.' The answer to that is, of course it's formalistic! The rule of law is about form." Antonin Scalia, Common-Law Courts in a Civil-Law System: The Role of United States Federal Courts in Interpreting the Constitution and Laws, in A MATter OF InTERPRETATION: FEDERAL COURTS AND THE LAW 3, 25 (Gutmann ed., 1997) [hereinafter Scalia, Common-Law]. See also Keith E. Whittington, Originalism: A Critical Introduction, 82 FORDHAM L. REV. 375, 379 (2013) ("The first point of substantial agreement among modern originalists is an emphasis on original meaning of the constitutional text. Justice Scalia has referred to this by the somewhat misleading label of 'textualism'").

51. "Among the three powers of which we have spoken, that of judging is in some fashion, null.” Montesquieu, The Spirit of The Laws 160 (Anne M. Cohler, Basia C. Miller \& Harold S. Stone eds. \& trans., Cambridge University Press 1989). 
also applies to Dworkin's "moral reading" originalism, albeit for very different reasons. ${ }^{52}$

For purposes of this Article, I will be using originalism and formalism interchangeably here. It is important to bear in mind, however, that there exists a notable sense in which formalism is broader an enterprise than originalism.

\section{ARTICLE V AND The ABSTRACT-CONCRETE ClAuSES DistinCTION}

\section{A. Bork's Originalist Argument}

Although this Part is going to debate Dworkin's account of constitutional clauses, I think the very best way to conceive of it remains as a critique of some traditional account of the U.S. Constitution, whose perfect example is Bork's adamant reconstruction. Therefore, I will be touching on the main traits of a "Borkean Constitution" for the purpose of a fruitful discussion of Dworkin's alternate interpretation-only to take the former back once the soundness of Dworkin's alternative has been put into question. ${ }^{53}$

In his famous book on the "political seduction of the law," 54 Robert Bork formulated a powerful rationale for an originalist account of the U.S. Constitution. More precisely, for holding that the Constitution was meant to be construed in an originalist fashion (what he notably described as "the original understanding of original understanding"). ${ }^{55}$ The argument hinges on the provision of rules for constitutional amendments, whose meaning would dangle in the air if "constitutional revisionism" considered a legitimate practice in the law. ${ }^{57}$

As Bork demonstrates,

[w] hen we speak of "law," we ordinarily refer to a rule that we have no right to change except through prescribed procedures. That

52. This is why Leiter, e.g., does not shrink from describing Dworkin as the "leading theoretical spokesman" of the "Sophisticated Formalists." Leiter, Legal Formalism, supra note 14, at 112 .

53. See infra Part III.

54. Robert H. Bork, The Tempting of America: The Political Seduction of the Law (1990) [hereinafter BORK, TEMPTING].

55. Id. at 153 .

56. By "constitutional revisionism," Bork refers both to the fact of judges who "legislate from the bench"- - what ordinarily goes under the name of "judicial activism"- and to theories that claim that the original understanding is not controlling of constitutional adjudication. See id. at 15-18. Although the issues are connected, they are not identical. Here, however, "constitutional revisionism" is simply synonymous with "judicial activism." See infra note 139.

57. BORK, TEMPTING, supra note 54, at 15. 
statement assumes that the rule has a meaning independent of our own desires. Otherwise there would be no need to agree on procedures for changing the rule. Statutes, we agree, may be changed by amendment or repeal. The Constitution may be changed by amendment pursuant to the procedures set out in article V. It is a necessary implication of the prescribed procedures that neither statute nor Constitution should be changed by judges. Though that has been done often enough, it is in no sense proper. ${ }^{58}$

Even if the idea of a "necessary implication" should not be taken literally, we could easily feel tempted to agree with Bork that the establishment of certain procedures for the amendment of the Constitution is presumably deemed to exclude the legitimacy of different, unentrenched modes of constitutional change (e.g., we would hold illegitimate a constitutional amendment formally enacted by the sole President of the United States, even if acclaimed in a subsequent popular vote). ${ }^{59}$ Were judges supposed to update the "referential content of a rule"-which Brest described as the sum of its "subjective exemplary applications" and its "conventional exemplary applications" 60 - to current times" different worldviews, what would be the point in arranging Article V's procedures?

It is important to emphasize that, for the purposes of this research, the Borkean descriptive model of abstract clauses is not "flawed" merely because of the reality of nonoriginalist judicial practice. ${ }^{61}$ As long as it is possible to give a qualification to this nonoriginalist behavior-namely, an

58. Id. at 143 .

59. But see Akhil R. Amar, Philadelphia Revisited: Amending the Constitution Outside Article V, 55 U. CHI. L. REV. 1043, 1044 (1988) ("I believe that the first, most undeniable, inalienable and important, if unenumerated, right of the People is the right of a majority of voters to amend the Constitution - even in ways not expressly provided for by Article V."). See also Akhil R. Amar, The Consent of the Governed: Constitutional Amendment Outside Article V, 94 Colum. L. REV. 457 (1994). Contra Henry P. Monaghan, We the People [s], Original Understanding, and Constitutional Amendment, 96 Colum. L. ReV. 121, 158-59 (1996). See also Brannon P. Denning, Means to Amend: Theories of Constitutional Change, 65 TENN. L. REV. 155, 191-92 (1997).

60. Brest, supra note 49, at 21. In describing one lawmaker's intentions in regard to some enacted ordinance, Brest identified three sources that make up for the rule's reference: First, the "instances of the rule's application which passed through [the lawmaker's] mind during the process of adopting it" (i.e., "the subjective exemplary applications of the rule"); secondly, the instances entailed by the "the language of the rule you drafted, which implies conventional exemplary applications" (i.e., "those [instances] that your language would suggest to other members of your society"); possibly, "the undesirable consequences that you hoped to avoid by enacting the rule" might make their way to the rule's referent. $I d$. However, in regard with this third element of the rules' content we might go a little further in Brest's tentative doubt ("though I am not certain how independent this is from the first two") and dismiss it beforehand: The "undesirable consequences" are either included in the first two sources of law's referent or inhere the abstractive thinking of the "sublimation of intention" I will try to reject in Part II, and therefore do not take part in the rule's referent.

61. See supra Introduction. In the case of Bork, constitutional practice is nonoriginalist when it is not controlled by the "original understanding." See BORK, TEMPTING, supra note 54, at 143-60. 
“improper behavior"- the descriptive capability of Bork's account is not completely impaired. ${ }^{62}$ Instead, the challenge abstract clauses pose to Borkean originalism is a more radical one, since their actual legal change is illegitimate from an originalist point of view and at the same time hardly any originalist would demand that they are legitimately changed. ${ }^{63}$ The factual impracticality of the Borkean model is what ultimately thwarts a fully originalist description of American constitutional practice. ${ }^{64}$

A major rejection of Bork's argument is found in the interpretation of the U.S. Constitution asserted by Ronald Dworkin, whose peculiar originalism must be addressed before attempting any critique of the Borkean originalist account. ${ }^{65}$ Were Dworkin's ideas sound and reliable, a flaw in the Borkean originalist model would be meaningless. Moreover, there is an expository benefit in postponing the critique of Borkean originalism: Its failure, as we will see, yields something of greater interest than the pitfalls of Dworkin's account.

\section{B. The Abstract Clauses of the Constitution and "Expectations Originalism",}

While discussing the Eighth Amendment's Cruel and Unusual Punishments Clause, Dworkin stated:

We have to choose between an abstract, principled, moral readingthe authors meant to prohibit punishments that are in fact cruel as well as unusual . . . - and a concrete, dated reading - they meant to say that punishments widely thought cruel as well as unusual at the time they spoke ... are prohibited. If the correct interpretation is the abstract one, then judges attempting to keep faith with the text today must sometimes ask themselves whether punishments the Framers would not themselves have considered cruel - capital punishment, for example-nevertheless are cruel . . . . If the correct interpretation is the dated one, on the other hand, these questions would be out of place, at least as part of an exercise in textual fidelity, because the only questions a dated understanding would pose is the question of what the Framers or their audience thought. ${ }^{66}$

62. See infra Part III.A.

63. See infra Part III.A.

64. See infra Part IV.B.

65. See infra Part II.

66. Dworkin, The Arduous Virtue, supra note 36, at 1253. 
Dworkin talks here of two "readings" of the Eighth Amendment's clause-an "abstract" and a "concrete" one. At a general level, he is positing a fundamental distinction between two types of clauses: "concrete clauses"- such as Article II's requirement that the President of the United States "have attained to the Age of thirty five Years" ${ }^{\text {" }}$ — and abstract ones (e.g., the Cruel and Unusual Punishments Clause) ${ }^{68}$

A concrete clause "commands what it says" and calls for an ordinary application of the law. ${ }^{69}$ In contrast, an abstract clause demands that judges make a "moral judgment": ${ }^{70}$ The judge's task regarding abstract clauses is not to seek the possible understanding of the clause at the time of enactment (i.e., in the case of the Cruel and Unusual Punishments Clause, the punishments widely thought cruel and unusual at the time of the Framers). Instead, judges are supposed to ask themselves what would be considered an instance of the clause, had it been enacted today. ${ }^{71}$ For clauses such as the Eighth Amendment's prohibition, the Framers did not merely mean to outlaw the specific behaviors covered by those clauses at the time of their enactment, but to establish provisions that prohibited all such future behaviors.

To conceive of an abstract clause as a concrete one is surely possible: Indeed, this is the very error all Borkean originalists make. ${ }^{72}$ Conversely, when interpreted as abstract clauses, concrete clauses end up ascribing "silly" intentions to the Framers. ${ }^{73}$ This is how we determine which clauses are concrete: It is a "Silliness test." For example, the requirement that the President of the United States be at least 35 years of age can surely be construed as whatever age might be indicative of due emotional age. ${ }^{74}$

67. U.S. CONST. art. II, $\S 1$, cl. 4.

68. For one of the first scholarly uses of the concrete-abstract clauses distinction to describe Dworkin's constitutional interpretation see Connie S. Rosati, The Moral Reading of Constitutions, in THE LEGACY OF RONALD DWORKIN 323, 325 (Wil Waluchow \& Stefan Sciaraffa eds., 2016). I guess it is not reckless to say that Dworkin's clauses' distinction is a projection of its rules-principles distinction. See DwORKIN, The Model of Rules I, in TAKING RightS SERIOUSLY 14 (1977) [hereinafter DWORKIN, TAKING RIGHTS SERIOUSLY]. It might be Dworkin's interpreters' competence to decide which has caused which (i.e., if the abstract clauses of the Constitution have prompted the idea of legal principles, or vice versa).

69. See infra Part III.A.

70. Dworkin, The Arduous Virtue, supra note 36, at 1254-55.

71. Id. at 1253 . clause).

72. See infra Part III.A (exploring an interpretation of the Eighth Amendment as a concrete

73. Dworkin, The Arduous Virtue, supra note 36, at 1252.

74. Id. (emphasis added). See also Mark V. Tushnet, A Note on the Revival of Textualism in Constitutional Theory, 58 S. CAL. L. REV. 683, 686-87 (1985) (contemplating extensive interpretations of the clause). 
The "due emotional age" could have been 35 years at the time but be different now, at a future historical moment. ${ }^{75}$

This, however, cannot be the case since, as Dworkin says,

[i]t would have been silly of them to have conditioned eligibility for the presidency on a property so inherently vague and controversial as that of emotional age, and there is no evidence of any such intention. We can make sense of their saying what they said only by supposing them to have meant chronological age. ${ }^{76}$

We can make the best sense of Dworkin's "making the best of" arguments when read as "inferences to the best explanation," although this reading does not always seem as viable as in this instance. ${ }^{77}$

The outlined summary may seem complicated, and even though Dworkin's theory's sketchy state makes every attempt to elucidate it a tentative operation, we can gain clarity from breaking it down. To explain the difference, we can once again consider the Cruel and Unusual Punishments Clause, which can be interpreted both as a concrete clause and as an abstract clause. If interpreted as "concrete," the clause displays the familiar form $\forall(\mathrm{x})\left(\mathrm{P}_{\mathrm{t}} \mathrm{X} \rightarrow F x\right)$ where $\mathrm{P}$ is the relevant property (i.e., $\mathrm{P}$ $=$ being cruel and unusual), $\mathrm{F}$ is the property of "being Forbidden" and $t$ is the clause enactment's time (i.e., in the case of the Eighth Amendment, $t_{1}$ $=1791$ ). If we hold it to be abstract, instead, the complexity of the clause increases because the time-reference becomes a variable itself and not a fixed value: Abstract clauses show a logical structure of the type $\forall(\mathrm{x})$ $\left(\mathrm{P}_{\forall(\mathrm{Y}) \mathrm{X}} \rightarrow F x\right)$ where $\forall(\mathrm{Y})$ would be the time at which the reader interprets the clause: most significantly, the time at which the judge is required to

75. "[W]hat would be alarming to several contemporary politicians ...." Dworkin, The Arduous Virtue, supra note 36, at 1252.

76. Id.

77. Dworkin's "it-would-be-silly" or "make-the-best-sense" arguments can be framed as inferences to the best explanation (i.e., among several possible interpretations of the same evidential data we choose the ones that are explanatorily superior). See Igor Douven, Abduction, STAN. ENCYCLOPEDIA PHIL. (Apr. 28, 2017), https://plato.stanford.edu/archives/sum2017/entries/abduction/ [perma.cc/95KX-76XZ] (discussing inference to the best explanation). In some instances, Dworkin explicitly mentions the expression "best explanation." DWORKIN, FREEDOM's LAW, supra note 35, at 2. However, it is hard to reduce all of Dworkin's kindred statements to inferences to the best explanation. Consider, e.g., his contention that the Equal Protection Clause cannot be reduced to a ban on hidden discriminations so that overt racial differentiations be permitted. See id. at 9 . That must be so, Dworkin explains, for "Congressmen of the victorious nation, trying to capture the achievements and lessons of a terrible war, would be very unlikely to settle for anything so limited and insipid ...." $I d$. (emphasis added). This kind of statement seems more properly significant if explained through Dworkin's troublesome belief in some objective morality, rather than read as an inference appealing to explanatory purposes. See infra Part II.B.2 (rejecting Dworkin's interpretation on the grounds of least ontological commitment). 
apply the clause (e.g., $\left.t_{2}=2021\right){ }^{78}$ The reference of Dworkinian abstract clauses is thus peculiarly context-dependent. ${ }^{79}$

Of course, Dworkin's use of expressions such as "considered cruel" or "thought cruel" 80 when speaking of punishments under the Eighth Amendment raises the question: what is the point of view under which these concepts are to be evaluated? Supporters of capital punishment and abolitionists, for example, may retain quite different ideas about which punishments are "in fact . . . cruel and unusual." ${ }^{81}$ Dworkin seems aware of this issue:

Does that mean punishments that the authors thought were cruel or (what probably comes to the same thing) punishments that were judged cruel by the popular opinion of their day? Or does it mean punishments that are in fact-according to the correct standards for deciding such matters-cruel? ? $^{82}$

The Silliness test, however, works only as an exclusionary tool by which we can tell the concrete clauses from the abstract ones. Either we think there cannot be another type of clause, or we might need a positive criterion to discern the abstract clauses within the U.S. Constitution. Dworkin provides us with such by resorting to a loose inference from the "abstract language" the Framers used in crafting the other clauses of the Constitution:

The Framers were careful statesmen who knew how to use the language they spoke. We cannot make good sense of their behavior unless we assume that they meant to say what people who use the words they used would normally mean to say-that they used abstract language because they intended to state abstract principles. ${ }^{83}$

In other words, the abstract language reveals the nature of the clause itself. Leaving aside for a moment the question of the inference's soundness, one can still brood over how an abstract principle should factually play out: "Okay, you have persuaded us that your interpretation is sound, Professor

78. If the time reference $t 1$ is fixed in concrete clauses, in abstract clauses $t 2$ is itself a function of the interpreter's particular time.

79. The temporal shift is relevant to the extent it implies a change in the conventional understanding of linguistic expressions (e.g., the reference of "cruel and unusual punishments), which at the same time reflect a shift in the social sensibility toward factual matters (e.g., the societal perception of cruelty and usualness). See infra Part III.B.

80. Dworkin, The Arduous Virtue, supra note 36, at 1253.

81. Id.

82. Id. at 1252 .

83. Dworkin, The Arduous Virtue, supra note 36, at 1253. 
Dworkin, but how are we supposed to apply an abstract principle when we come across one?" Here Dworkin summons up his famous notion of "law as integrity": 84

We must ask: What is really cruel? What does equal citizenship really require? What legislation is consistent with due process of law, given that legal integrity is of the essence of law's process, and that integrity requires that the liberties our culture recognizes in broad principle - freedom of conscience, for example-must be respected in individual legislative decisions about, for example, freedom of choice in dying? ${ }^{85}$

One may wonder whether Dworkin simply names "integrity" what others would call "justice," so that the application of the Constitution merely calls for its evaluation in accordance with some external (allegedly superior) moral system. ${ }^{86}$ But Dworkin seems to dismiss this possibility. ${ }^{87}$ "Law as integrity" does not imply any mingling of adjudication with subjective political values (i.e., adjudication as to fit one own's personal idea of "integrity"), since law is not "political philosophy":

[A]ny strategy of constitutional argument that aims at overall constitutional integrity must search for answers that mesh well enough with our practices and traditions - that find enough foothold in our continuing history as well as in the Constitution's text-so that those answers can plausibly be taken to describe our commitments as a nation. If I were trying to answer the question of what equal citizenship means as a philosophical exercise, for example, I would insist that citizens are not treated as equals by their political community unless that community guarantees them at least a decent minimum standard of housing, nutrition and medical care. But if the Supreme Court were suddenly to adopt that view, and to announce that states have a constitutional duty to provide universal health care, it would have made a legal mistake, because it

84. "These are difficult questions. Citizens, lawyers, and judges should not try to answer them on a clean slate, ignoring the answers that others, particularly judges, have given to them in the past." Id. at 1254. Dworkin's "political integrity" consists of a "political" and an "adjudicative principle." See DWORKIN, LAW'S EMPIRE, supra note 30, at 178. What bears relevance to the present inquiry is the latter one. "According to law as integrity, propositions of law are true if they figure in or follow from the principles of justice, fairness, and procedural due process that provide the best constructive interpretation of the community's legal practice." Id. at 225.

85. Dworkin, The Arduous Virtue, supra note 36, at 1254 (emphasis added).

86. In this sense, Dworkin's "integrity" and Radbruch's "justice" would be one and the same. See Radbruch, supra note 49.

87. Dworkin, The Arduous Virtue, supra note 36, at 1255. 
would be attempting to graft into our constitutional system something that (in my view) doesn't fit at all. ${ }^{88}$

Dworkin does not make explicit how the application of the law, qua an exercise in "constructive interpretation," may be implying one when he warns against the conflation of the Framers' "semantic intentions" with their "political" ones: "It is a fallacy to infer, from the fact that the semantic intentions of historical statesmen inevitably fix what the document they made says, that keeping faith with what they said means enforcing the document as they hoped or expected or assumed it would be enforced." 90

Although Dworkin resorts to a controversial example to depict the distinction, ${ }^{91}$ we can glean the difference between semantic and political intentions from Dworkin's reply to Justice Scalia in a different occasion. ${ }^{92}$ If we assume that "expectation originalism" equates the interpretation by the said political intentions, then Dworkin provides us with a prima facie solution: "“[S]emantic originalism' . . . takes what the legislators meant collectively to say as decisive of constitutional meaning, and 'expectation originalism' . . . makes decisive what they expected to accomplish in saying what they did." ${ }^{.93}$ If that is the case, Dworkin's interpretation boils down to a rejection of what originalist scholarship has often called "expectations originalism." 94

This is not the only possible interpretation of Dworkin's words. As Keith Whittington hypothesizes, maybe Dworkin is simply maintaining that the Framers postulated the existence of moral entities such as an objective "concept of cruelty" (i.e., they assumed that "moral terms such as 'cruel' have real, substantive content apart from conventional beliefs"). ${ }^{95}$ The interpretation would agree, incidentally, with Dworkin's own "ungrounded value realism" where "moral conviction" happens to be coupled with "mathematics." "96 Is Dworkin really regarding moral entities

88. Id. at 1254 .

89. "We must begin, in my view, by asking what - on the best evidence available - the authors of the text in question intended to say. That is an exercise in what I have called constructive interpretation." Id at. 1252 .

90. Id. at 1255 .

91. See infra Part III.A (confronting this example as an instance of Dworkin's dubious conception of communication).

92. Dworkin, The Arduous Virtue, supra note 36, at 1257-58.

93. Id. at 1256.

94. Whittington, supra note 50, at 383 n.49 ("Ronald Dworkin forcefully argued against a kind of expectations originalism ....").

95. Keith E. Whittington, Dworkin's "Originalism”: The Role of Intentions in Constitutional Interpretation, 62 REVIEW OF POLITICS 197, 198-221 (2000).

96. RONALD DWORKIN, RELIGION Without GOD 13-14, 16-17, 89-90 (2013). 
as some sort of abstract object as classes and numbers? Is he further maintaining that the Framers held such a view?

As we shall see, these are key questions in coming to terms with Dworkin's scholarship. ${ }^{97}$ However, if that is the case, his ideas can hardly be subject to rational debate. ${ }^{98}$ Moreover, as Whittington and Lawson have pointed out, it would remain an open question for historical inquiry whether the Framers intended abstract clauses to refer to moral entities such as the true notion of "cruelty," or to some historical understanding thereof. ${ }^{99}$ It would be curious to envisage the fate of abstract clauses if it turned out that such moral entities-whose existence is, at best, controversial-were the Framers' expected referential content. What then if those moral objective entities happened not to exist?

For this study, I will assume Dworkin's reference to "political intentions" as synonymous to "expectations" or "expected applications originalism." Therefore, I argue that it is not necessary to engage in a historical reconstruction for rejecting Dworkin's view. One could simply realize how problematic Dworkin's account - as every interpretation that severs the link with the "expected applications" of any normative actbecomes from a strictly interpretative point of view. Were Dworkin correct in his approach, in fact, we would have to revise some traditional ideas on constitutional rigidity and, more generally, on action and commutative acts. And we might be well justified in refusing to do so.

\section{THE DWORKINIAN ORIGINALIST}

\section{A. Updating the Abstract-Concrete Clauses Distinction}

Before identifying the shortcomings in Dworkin's account, a fulfillment of his model can be profitably carried out. Taken at face value, the theory is exposed both to mild and serious criticism which can both be avoided through a refinement of Dworkin's theory.

97. See infra Part III.A.

98. I am holding here to some rough noncognitivist belief on the ethical discourse. "What we cannot speak about we must pass over in silence." LudWIG WitTGENSTEIN, TRACTATUS LOGiCOPHILOSOPhicus 89 (D.F. Pears \& B.F. McGuinnes trans., Routledge 2001) [hereinafter Wittgenstein, Tractatus]. See also LudWig Wittgenstein, Lecture ON Ethics: INTRODUCTION, INTERPRETATION AND COMPLETE TEXT 132-239 (Edoardo Zamuner, E. Valentina Di Lascio \& David Levy, eds. 2007) [hereinafter WitTGENSTEIN, ETHICS] (attacking rationalist reductions of the problem of justice and morality). It ought to be mentioned that Wittgenstein's thought has been interpreted also as a legitimization for some kind of moral cognitivism. See Patrick Oobuyck, Wittgenstein and the Shift from Noncognitivism to Cognitivism in Ethics, 36 METAPHILOSOPHY 381 (2005) (emphasizing the difference between foundationalism and cognitivism).

99. See Whittington, supra note 95, at 222; Lawson, supra note 21, at 1468-71. 
Dworkin only implied the following conclusion, which we have to explicate if we are to shield his theory from the range of Bork's argument. ${ }^{100}$ Unlike abstract clauses, concrete clauses are not only subject to, but also the reason for the existence of the amending rules set out in Article V. This is an important clarification insofar as it provides the model with a rationale for the procedures set out in Article V-thus supplying a "target" for their meaning. This refinement neutralizes the criticism from Bork, who held up the potential meaninglessness of Article V's procedures as a strong argument against the likelihood that constitutional judicial updates had been endorsed by the Framers. ${ }^{101}$

After this preliminary adjustment, Dworkin's account of constitutional rules has to undergo a more significant improvement, for its actual state paves the way to the aforementioned objection. When the judges who are supposed to perform the "moral judgment" seek the point of view from which to discern the several "objects of the world" that are meant to be encompassed by the clause at the moment of its application, ${ }^{102}$ who is the normative agent of the judgment? In the case of the Eighth Amendment, whose sense of cruelty and unusualness is to be used as touchstone in distinguishing a viable sanction from an abusive punishment? This is what John Stinneford appropriately calls "The Who Decides? Problem."103

In this respect, it is possible to buttress Dworkin's theory by assuming that judges apply the will of "the People of the United States" 104 by performing some broad democratic appreciation of the concept itself at any given time. The judge is thus deemed to assess, to the best of their abilities, the majority's opinion on the several concepts the abstract clause entails at the time of enactment. Insofar as originalism deems it possible to ascertain the intent of the Framers, or - in the "original public meaning version"105_ of a hypothetical "reasonable person" 106 at the time, the possibility of gauging what the majority of the population considers "cruel" or "unusual" in a certain moment does not seem to amount to any

100. BORK, TEMPTING, supra note 54, at 143.

101. Id.

102. That is, the punishments perceived to be cruel and unusual at the reader's time (" $\forall(\mathrm{Y})$ "). See supra Part I.B.

103. Stinneford, supra note 27 , at 1751.

104. U.S. CONST. pmbl.

105. As is widely known, "original intent originalism" centers on the subjective intentions of the Framers-somewhat differently from their "expected applications" of constitutional provisionswhereas the "original public meaning originalism" consists of the meaning a reasonable person would have gathered by reading the constitutional text at that time. See generally Whittington, supra note 50, at 375 (discussing the history and the key ideas revolving around originalism).

106. "[W]e do not really look for subjective legislative intent. We look for a sort of "objectified" intent - the intent that a reasonable person would gather from the text of the law ...." Scalia, Common-Law, supra note 50, at 17. 
heavier interpretative burden. In the same way, we can cope with the instinctive dissatisfaction that arises before Dworkin's puzzling use of "appraisive" 107 concepts (e.g., when he speaks of "punishments that are in fact cruel as well as unusual" without specifying what "in fact" actually refers to. "In fact," should read here as "at the time"). ${ }^{108}$

It bears noting that Dworkin's account happens to embody the U.S. Supreme Court's "Evolving Standards of Decency" jurisprudence. ${ }^{109}$ In the context of the proportionality of punishments, the Supreme Court stated that

if we are to attribute an intelligent providence to [the Cruel and Unusual Punishments] advocates, we cannot think that it was intended to prohibit only practices like the Stuarts', or to prevent only an exact repetition of history. We cannot think that the possibility of a coercive cruelty being exercised through other forms of punishment was overlooked. ${ }^{110}$

The evolving and forward-looking aspect of the clause finds itself generalized in Justice Cardozo's famous dictum that "the great generalities of the Constitution have a content and a significance that vary from age to age." 111

\section{B. The Sublimation of Intention: The Expensiveness of Dworkin's Reconstruction}

\section{The Purpose for a Rigid Constitution}

I shall call "sublimation of intention" the process of stripping the intention of an action of its foreseeable outcomes. In Dworkin's model, this takes place when abstract clauses are detached from their foreseeable

107. Walter B. Gallie, Essentially Contested Concepts, 56 Proc. ARISTOTELIAN SOC'Y 167, 171 (1955-1956).

108. Dworkin, The Arduous Virtue, supra note 36, at 1253 (emphasis added). But see infra Part III.B (interpreting Dworkin as a metaphysical scholar who admitted the existence of moral entities).

109. See, e.g., Roper v. Simmons, 543 U.S. 551, 551 (2005) ("The Eighth Amendment's prohibition against 'cruel and unusual punishments' must be interpreted according to its text, by considering history, tradition, and precedent, and with due regard for its purpose and function in the constitutional design. To implement this framework this Court has established the propriety and affirmed the necessity of referring to 'the evolving standards of decency that mark the progress of a maturing society' to determine which punishments are so disproportionate as to be 'cruel and unusual"'). The "evolving standard of decency" formula was historically coined in Trop v. Dulles, 356 U.S. 86, 101 (1958).

110. Weems v. United States, 217 U.S. 349, 373 (1910).

111. Benjamin N. Cardozo, The Nature of Judicial Process 17 (1921). 
instances of application (i.e., the cases the Framers conceived or would have regarded as regulated by those clauses) and turn them into empowerment on future interpreters to restate the referential content of those clauses. ${ }^{112}$ The sublimation consists of climbing from one concrete layer of intention (e.g., "flogging is forbidden") to a higher one (e.g., "since flogging has been forbidden because it was deemed an excessively cruel punishment, then all excessively cruel punishments are to be forbidden"). The reasoning may then increase: "Since excessively cruel punishments were forbidden because they were deemed excessively cruel acts, then all excessively cruel acts are to be forbidden"; "since excessively cruel acts have been forbidden because they were deemed wrong acts, then all excessively wrong acts are to be forbidden," and so forth.

As Bork originally posited, while considering Griswold v. Connecticut's principle that the State of Connecticut's statute prohibiting the use of contraceptives by married couples was unconstitutional on the grounds of an expanded "right to privacy": 113

Why does the principle extend only to married couples? Why, out of all forms of sexual behavior, only to the use of contraceptives? Why, out of all forms of behavior, only to sex? The question of neutral derivation also arises: What justifies any limitation upon legislatures in this area? What is the origin of any principle one may state ${ }^{114}$

In Wechsler's wake, ${ }^{115}$ Bork framed the phenomenon as an issue over the "neutral definition of principle" 116 but it is often scholarly referred to as the quest for the principle's proper "level of generality" or "level of abstraction." $" 117$

112. See supra Part I.B.

113. Griswold v. Connecticut, 381 U.S. 479, 485 (1965).

114. Robert Bork, Neutral Principles and Some First Amendment Problems, 47 IND. L.J. 1, 7 (1971) [hereinafter Bork, Neutral Principles].

115. See Herbert Wechsler, Toward Neutral Principles of Constitutional Law, 73 HARV. L. REV. 1 (1959) (arguing for a neutral application of the constitutional rules).

116. Bork, Neutral Principles, supra note 114, at 2.

117. Bork himself eventually yielded to this second choice of words, which has many other supporters. See, e.g., Robert H. Bork, Foreword to GARY L. MCDOwELL, THE CONSTITUTION AND CONTEMPORARY CONSTITUTIONAL THEORY, at xi (1985) [hereinafter Bork, Foreword]; Mark V. Tushnet, Following the Rules Laid Down: A Critique of Interpretivism and Neutral Principles, 96 HARV. L. REV. 781, 791 (1983); Laurence H. Tribe \& Michael C. Dorf, Levels of Generality in the Definition of Rights, 57 U. CHI. L. REV. 1057 (1990); Raoul Berger, An Anatomy of False Analysis: Original Intent, 1994 BYU. L. REV. 715 (1994). Some scholars had conversely opted for the expression "level of abstraction." See, e.g., Paul Brest, The Fundamental Rights Controversy: The Essential Contradictions of Normative Constitutional Scholarship, 90 YALE L.J. 1063, 1084-85 
The problem with this "sublimation of intention" is the legal puzzle it leads to: What is the point of enacting rules at a constitutional level (i.e., a level conceived not to be subject to the democratic majority rule) if they are subsequently meant to change over time through the same democratic appreciation $^{118}$ the constitutional status should have preserved them from? If overcoming majoritarian democracy by withdrawing some rights from majority-rule deliberation is the rationale for a rigid Constitution, then Dworkin's abstract clauses contradict this end.

As Judge Frank Easterbrook has succinctly written,

If the living legal community is indeed the right benchmark, it is tempting to ask: why a constitution? A written constitution . . . is designed to be an anchor in the past. It creates rules that bind until a supermajority of the living changes them. You can imagine change by the living in ways other than those described; after all, our Constitution was ratified without the unanimity required by the Articles of Confederation. That constitutional change requires a supermajority sustained over an extended period cannot be doubted, however-for to doubt it is to doubt the ability of the past ever to constrain the present, and thereby to destroy the source of the judges' claim to countermand the will of contemporary majorities. Yet putting questions about the level of abstraction to today's legal community dispenses with both the supermajority requirement and the need for some stability in that opinion (which must endure long enough to obtain a two-thirds vote in both chambers of Congress and a majority in three-fourths of the states' legislatures, a process that takes considerable time). ${ }^{119}$

The idea of the judicial modification of the clauses of the Constitution does not seem to comport with the rationale that underpins a rigid constitution. If the Framers of the United States Constitution wanted every subsequent generation to enforce its conception of a "cruel and unusual punishment"-and not merely adhere to those from the time of enactment-would it not have been a shorter and more economic route to leave the topic deregulated, and therefore apt to being addressed by the ordinary democratic process? Why establish a rigid Constitution-which mandates supermajority legislative consensus to amend certain

(1981); Michael W. McConnell, Originalism and the Desegregation Decisions, 81 VA. L. REV. 947, 952 (1995).

118. See supra Part II.A $₫ 4$.

119. Frank H. Easterbrook, Abstraction and Authority, 59 U. CHI. L. REV. 349, 363 (1992). 
provisions - if the implied goal was to apply those provisions in the way most people would conceive of them, in all future times?

\section{Three Auxiliary Hypotheses and Their Expensiveness}

The only way to address this controversial question-why a rigid Constitution if it was conceived to be amended through some judicial "moral reading" "120 that ultimately replicates the ordinary majority ruleentails resorting to some implicit intentions on the part of the Framers. An auxiliary hypothesis has to fill in for the apparent inconsistency, and three seem especially worthy of consideration.

First, we may think the Framers nurtured the hope that future generations could subsume their different conceptions into the same legal text to engender an illusion of eternity, continuity, and stability for those clauses and the legal system they were going to underpin. ${ }^{121}$ As Brest notes, "[b]elief in the continuing authority of the Document may contribute to a sense of national unity and to law-abiding behavior by officials and citizens."122

In the case of abstract clauses, judges would take care of updating their meaning to fit new circumstances, but it is important that constitutional wording remains the same for continuity appearances: Even though, that is, the Framers would have never held those instances as legitimate applications of the clause. In this sense, the Constitution is materially eternal, but subject to different interpretations throughout history, similarly to what happens with religious "timeless" texts. ${ }^{123}$ The Framers implicitly endorsed this amending procedure-alternative to the one set forth in Article V and left to the judges to carry out-when they attached the Bill of Rights to the Constitution. In this sense, it is the Constitution itself that demands that "[j] ustices . . . be able to maintain an illusion of adherence to legal principle." 124

The second hypothesis might go further and claim that the Framers sought to withdraw the valuation of concepts like "cruel and unusual punishment" to the democratic process itself by equipping judges with

120. DWORKIN, FREEDOM's LAW, supra note 35, at 13.

121. See Samuel L. Levine, The Constitution as Poetry, 49 Seton Hall L. ReV. 737 (2019) (making a compelling case for the resemblance of the Constitution and the Torah as timeless texts designed to be differently interpreted throughout history).

122. Brest, supra note 49 , at 234.

123. See Levine, supra note 121 , at $752-55$.

124. Cross, supra note 21, at 530 (discussing the pretense of legality of the Supreme Court's decisions). 
elastic tools for overriding democratically enacted decisions. ${ }^{125}$ Since they did not want to highlight this anti-democratic aspect of the Constitution, they concealed it within the peculiar language of these clauses. This is a more extreme version of the first hypothesis: Not only judges claim to apply the original law when what they are really doing is updating it to the current conceptions of the majority. Here, they are supplanting the will of the people with their own.

This interpretation overlaps with the idea that the Bill of Rights does not amount to a historical set of rights and liberties granted to all the citizens of the United States, but rather to the empowerment of specific agents with the capacity of inoculating substantive policies by means of those clauses. ${ }^{126}$ Surely rigid constitutions are per se anti-democratic to the extent they withdraw some policy areas from majority rule democracy. ${ }^{127}$ Nonetheless, a precise and historically circumscribed limitation of democracy (i.e., the structure of government, some specific rights, certain power-conferring rules, etc.) is different from the inexplicit establishment

125. Much like the case of the "conspiracy theories" of the Fourteenth Amendment. See RAOUl BERGER, GOVERNMENT BY JUdiCIARY: THE TRANSFORMATION OF THE FOURTEENTH AMENDMENT 122 (2d ed., 1997) (framing Bickel's "open-ended" phraseology theory as a conspiracy theory); Howard J. Graham, The "Conspiracy Theory" of the Fourteenth Amendment, 47 YALE L.J. 371 (1938) (debating the Republican alleged plot to allow corporations and business to enter the notion of "person" in the Due Process Clause).

126. This is, again, Dworkin's idea that the abstract language the Framers employed points to the empowerment of judges to do the kind of adjudication Borkean originalists would regard as overreaching. This line of reasoning is not, for Dworkin, an interpolation of the Framers' ideas but true adherence to their original intent: American citizens should apply the true idea of moral ideas such as "cruel," even though the Framers, as it were, had gotten the law wrong-as in the case, e.g., of the Framers' likely assent to school segregation. "The moral reading insists that they misunderstood the moral principle that they themselves enacted into law." DWORKIN, FREEDOM's LAW, supra note 35, at 13. However, I think Dworkin would have hardly consented to this auxiliary hypotheses as I presented it: As is widely known, one of the main points in Dworkin's scholarship was to contrast the idea that judges claim to do something - namely, apply the law-while what they are doing is something elsethat is, making up the law. See DWORKIN, LAW'S EMPIRE, supra note 30, at 6-11 (criticizing the plainfact view under which if lawyers and judges disagree over the law in some cases, they must be really arguing over what the law should be). Dworkin argues that the judicial update of constitutional clauses was overtly called upon by the abstract language the Framers employed, and we should, consequently, stop bewildering over this kind of judicial activism ("There is therefore a striking mismatch between the role the moral reading actually plays in American constitutional life and its reputation. It has inspired all the greatest constitutional decisions of the Supreme Court, and some of the worst. But ... it is almost never openly endorsed even by judges whose arguments are incomprehensible on any other understanding of their responsibilities"). DWORKIN, FREEDOM'S LAW, supra note 35, at 3. Moreover, it is telling a fact that, aside from Dworkin, there has been little support for an "original understanding of judicial enforcement" among supporters of judicial activism. Indeed, arguments for judicial enforcement of the Bill of rights have generally rested in some better "natural" ability of the judges in enforcing fundamental rights. See, e.g., Frank B. Cross, Institutions and Enforcement of the Bill of Rights, 85 CORNELL L. REV. 1529, 1536-50 (2000) (critically recalling several similar positions).

127. That is the cause of the "countermajoritarian difficulty": "The root difficulty is that judicial review is a counter-majoritarian force in our system." ALEXANDER M. BICKEL, THE LEAST DANGerous Branch: THE SuPReme Courts AT THE BAR of Politics 16 (2d ed., 1986). 
of an authority capable of permanently overriding majority decisions in some areas of the law. Arguing that judges are better suited to rights enforcement means only begging the question of whether it was the amender's historical purpose to entitle them to do so. ${ }^{128}$ It bears emphasizing, however, that this second hypothesis is at variance with my second adjustment of Dworkin's theory: If the Framers aimed to empower judges with this anti-democratic ability, then it is impossible to hold that they were also expected to appreciate the majority's opinion on abstract concepts such as a "cruel and unusual punishment[].",

As a third possibility, ${ }^{130}$ the Framers' purpose for the Cruel and Unusual Punishments Clause was more limited: to deny lawmakers the possibility of enacting punishments the lawmakers themselves would have considered "cruel and unusual." 131 Times of particular social danger and distress might bring people to demand extremely harsh and exemplary punishments. ${ }^{132}$ People may urge legislatures to enact penalties the people themselves regard as cruel and unusual: Cruel and unusual crimes call for cruel and unusual punishments, the slogan might go.

In this case, the Eighth Amendment would quash this very possibility. People and legislatures can use whatever punishments they want, insofar as they do not claim to be inflicting "cruel and unusual punishments." The Cruel and Unusual Punishments Clause dictates that crimes, no matter how heinous, not be answered with penalties the people and the legislatures themselves would consider to be "cruel and unusual." What the abstract clause bans here is the familiar principle of "an eye for an eye." $" 133$

These three reconstructions share in the idea that the concepts of cruelty and usualness considered in adjudication can differ from the ones the Framers retained at the time of enactment. Moreover, the first one (i.e., the "pretense of continuity theory"134) and the third one (i.e., the "antiretributionist theory"135) comport with the idea of the "democratic

128. For some critical stances toward the alleged benefits of the Bill of Rights' judicial enforcement see Cross, supra note 126, at 1536-73.

129. U.S. CONST. amend. VIII.

130. I thank Eugenio Vezzosi for signaling to me this possibility while discussing the topic.

131. U.S. CONST. amend. VIII.

132. See John F. Stinneford, Rethinking Proportionality Under the Cruel and Unusual Punishments Clause, 97 VA. L. REV. 899, 907, 969-70 (2011) (discussing how legislatures ratchet up criminal penalties during critical moments).

133. See Morris J. Fish, An Eye for an Eye: Proportionality as a Moral Principle of Punishment, 28 OXFORD J. LEGAL STU. 57 (2008) (making a compelling case for conceiving of the retaliation principle as a historical improvement of criminal punishment).

134. See supra Part II.B.2.

135. See supra Part II.B.2. 
appreciation" mentioned above. ${ }^{136}$ In fact, we can probably dismiss the second reading of the clause (i.e., the "conspiratorial theory"137) by simply shifting the burden of proof: The onus probandi of the concealed intention of "judicial supremacy" "138 rest on their proponents. If judicial activism had no relevant backing at the Framers' time, ${ }^{139}$ while the separation of power theme was held on the highest esteem, ${ }^{140}$ it is plausible that the burden of proof would rest on the supporters of judicial supremacy view, not on the traditional, linguistically-plainer one. The evidential question is difficult, for if the Framers had such an "unspeakable" intention (i.e., to empower judges with normative powers without making it manifest) they arguably omitted to acknowledge it in their writings or proceedings. Inferring from silence, that is, is always a hard task.

However, two auxiliary hypotheses would emerge unimpaired by this simple argumentation. ${ }^{141}$ Therefore, we are still in want of something more to decide whether the Dworkinian foundation of the judicial update of abstract clauses, when supported by these auxiliary hypotheses, is ultimately sound.

My refutational argument hinges on the linguistic difference between two kinds of rules that Hart has famously categorized for us when rejecting Austin's imperative theory: the distinction between primary and secondary rules. ${ }^{142}$ Rules of the first type qualify individual behavior as prohibited, permitted or obligatory, and thus are traditionally identified with statutes that criminalize certain behaviors or oblige people to pay their taxes. Secondary rules, instead, comprise both rules that bestow on certain public subjects the authority to do something (e.g., the constitutional provision that dictates how the parliament can lawfully enact the said criminal statute, the precedent that empowers a court to void

136. See supra Part II.A-B.1.

137. See supra Part II.B.2. Here, the "conspiratorial idea" that the framer secretly wanted that the judges, not the people, to decide what is a "cruel and unusual punishment."

138. Cross, supra note 126 , at 1530.

139. Needless to say, by "judicial activism" I mean the natural phenomenon of judges overstepping their bounds and acting qua legislature. See Frank B. Cross \& Stefanie A. Lindquist, The Scientific Study of Judicial Activism, 91 MINN. L. REV. 1752 (2007) (recollecting the history of judicial activism in the United States); Keenan D. Kmiec, The Origins and Current Meanings of "Judicial Activism," 91 CAL. L. REV. 1441, 1445-50 (2004) (discussing the history and meaning of "judicial activism"). The point is that there is scarce evidence this approach could have been endorsed by the Framers: This is the central argument in Bork's "original understanding of original intent." BORK, TEMPTING, supra note 54, at 153-55. (1969).

140. Cf. Gordon Wood, The Creation of the American Republic 151-61, 176-87,

141. Precisely, the "pretense of continuity" and the "anti-retributionist" theories. See supra Part II.B.2.

142. See Herbert L.A. Hart, The Concept of LaW 79-99 (3d ed. 2012) (describing the "heart of a legal system" as the sum of primary and secondary rules). 
the criminal statute if found in conflict with some constitutional rules, etc.) and rules that give private acts a particular legal relevance (e.g., the consensus of two individuals before an official, given certain conditions, may unite them in marriage). In Hart's words: "Rules of the first type impose duties; rules of the second type confer powers, public or private."143

We can observe several instances of these two types of rules in constitutional law. For example, when the Constitution says that the Congress has the power to "regulate Commerce with foreign Nations, and among the several States, and with the Indian Tribes,"144 it may certainly be controversial what "Commerce" means, but we might be pretty confident that we are facing a primary rule that grants a certain public entity (i.e., the Congress) the power to adopt binding decisions in that subject. ${ }^{145}$ Conversely, it might be disputable what "adhering to [the United States'] Enemies, giving them Aid or Comfort" may factually mean, but it is not an overreach to affirm that the Constitution forbids "Treason." "146 How can we be so sure about the different nature of the two clauses? For the very linguistic formulation generally helps us in distinguishing. In the case of Commerce Clause, we have an explicit conferment of power- " $[t]$ he Congress shall have Power" case of Treason we can infer the unlawfulness of Treason-a contrariisfrom the foreshadowing of trial as a consequence. ${ }^{148}$

In this respect, Dworkinian abstract clauses present us with a curious puzzle. The Cruel and Unusual Punishments Clause, for example, is linguistically shaped as a primary rule: It seems to suggest that, if "openended," there exists a set of punishments that are "cruel and unusual," and that set is forbidden. Nonetheless, in Dworkin's interpretation, the clause behaves like a secondary rule insofar as it is understood as empowering judges, either to enforce their personal views or to appreciate the current

143. Id. at 81 .

144. U.S. CONST. art. I, § 8, cl. 3.

145. See, e.g., RANDY BARNETT, RESTORING THE LOST CONSTITUTION: THE PRESUMPTION OF LIBERTY 278-97 (2004) (discussing the original meaning of "commerce").

146. U.S. CONST. art. III, $\S 3$.

147. U.S. CONST. art. I, $\S 8$, cl. 1 .

148. There is little doubt that the Treason Clause describes a criminal offense and thus a primary rule. See, e.g., George P. Fletcher, The Case for Treason, 41 MD. L. REV. 193, 193 (1982) ("[T]reason is the only crime to find definition in our basic document"). Treason is especially relevant to the history of American law. Id ("[T] law"). Despite scholarly obsolescence, the Clause has regained attention with the Bush Administration's "war on terror" and the legal condition of terrorists. See, e.g., Carlton F. W. Larson, The Forgotten Constitutional Law of Treason and the Enemy Combatant Problem, 154 U. PA. L. REV. 863 (2006) (contending that the Treason Clause should be used to regulate enemy combatant detentions). 
majority understandings of a "cruel and unusual punishment." Thus, the essence of the Dworkinian Clause is that of a secondary rule, rather than a primary one. It is a secondary rule shaped in the language of a primary rule. If the same holds true with other abstract clauses, we can say that, for Dworkin, abstract clauses happen to be secondary rules disguised as primary rules.

But if that is the case, we are admitting the existence of a third type of rules (this "secondary-qua-primary" rules). The move is "ontologically expensive" insofar as it introduces an additional category. If we have no external element in deciding whether to accept the provision as a "secondary-qua-primary" rule or to interpret it as a normal primary rule (i.e., a rule with a fixed, if "open-ended," referential domain), we should stand for the latter possibility as it would make our legal world less populated. That is, if we assume that one quality of any scientific account is its "least ontological commitment," Dworkin's position winds up expensive as it admits of this third kind of rules, i.e., secondary rules worded as primary rules. ${ }^{149}$

In this sense, the whole argument against Dworkin's account and the auxiliary hypothesis can be construed as an inference to the best explanation. ${ }^{150}$ The rejection of his amending account can thus be advocated on the grounds that, ceteris paribus, it burdens legal ontology with an additional, unnecessary legal category.

\section{The Deficiency of the Sublimation and Some Quirks on Agency and Communication}

\section{Arresting the Sublimation}

If Dworkin's model seems ontologically expensive, one may question it, conversely, for playing out somewhat "deficient," as it fails to provide the rationale for the sublimation's arrest at a certain level of abstraction. As for the criterion that should stop the abstraction from historical

149. See Willard V.O. Quine, On What There Is, 2 ReV. Metaphysics 21, 33 (1948), reprinted in Willard V.O. QUINE, From a LOGICAL POINT OF VIEW: 9 LOGICO-PhILOSOPHICAL ESSAYS 13-14 (Harper \& Row 2d ed. 1963) (describing the ontological commitment of theories as "those and only those entities to which the bound variables of the theory must be capable of referring in order that the affirmations made in the theory be true").

150. See Douven, supra note 77. According to Harman's locus classicus, in the inference to the best explanation, "one infers, from the premise that a given hypothesis would provide a 'better' explanation for the evidence than would any other hypothesis, to the conclusion that the given hypothesis is true." Gilbert H. Harman, The Inference to the Best Explanation, 74 PHIL. REV. 88, 89 (1965). 
instances of the abstract clauses, the interpreter might feel left in the lurch by Dworkin.

We might reconsider the Eighth Amendment and ask ourselves: "Why stop at the ban on behaviors that stand against the sense of cruelty and unusualness?" At a deeper psychological level, the Framers wanted to outlaw cruel and unusual punishments because they were "wrong." If we are to fulfill this abstract level of intention, why should we not hold prohibited every behavior which might be considered "wrong," either as against the sense of cruelty or against the sense of shame, or the sense of respect for others, or of reliability on one's words, etc.? Why settle for the sub-cluster and not walk down the deeper level of agency-or "ascend" to the higher level of abstraction - at which the Framers acted in order to ban every behavior that would have been subsequently considered "wrong"?

And what about the "positive side" of every prohibition, which is to promote, so to speak, justice or the common good? It seems possible to argue that at some deep level of agency there is no difference between, for example, a constitutional clause that forbids statutes curbing freedom of speech and a provision that forbids federal legislation compelling states to pay taxes for the national welfare. They both arise out of an intention of doing-what-is-right, from which we may derive new clauses only slightly related with the reference of the originally enacted one. And yet sharing the same volitive, causal urge. Why should one not think that the Framers meant future interpreters to call upon this abstractive regression?

Scalia and Garner perfectly emphasize the point:

The most destructive (and most alluring) feature of purposivism is its manipulability. Any provision of law or of private ordering can be said to have a number of purposes, which can be placed on a ladder of abstraction. A law against pickpocketing, for example, has as its narrowest purpose the prevention of theft from the person; and then, in ascending order of generality, the protection of private property; the preservation of a system of private ownership; the encouragement of productive activity by enabling producers to enjoy the fruits of their labor; and, finally, the furtherance of the common good. The purposivist, who derives the meaning of text from purpose and not purpose from the meaning of text, is free to climb up this ladder of purposes and to "fill in" or change the text according to the level of generality he has chosen. ${ }^{151}$ LEGAL TEXTS 18-19 (2012). 
As Sai Prakash and Larry Alexander write, in an attempt to save intentionalist originalism from the doom of purposivism, "[ $\mathrm{t}] \mathrm{he}$ intentionalist does not advocate ascending up the ladder of generality of intention, at the pinnacle of which all laws turn out to be the Spike Lee law: do the right thing." "152

Imagination might allow for even bolder interpretative flights than the "Spike Lee Law." If "intentions are what matter," we might further concede that the basic intention of every action is "bringing something about." 153 Would it be possible, then, to equate two different rules since they both were made out of an "urge to do something"? But then again, what would be the difference between the action of making up a rule and that of cooking pancakes? And how to justify the presence of multiple provisions concerning individual rights in the Constitution, if this abstractive reasoning were at our disposal? Why, given just one provision (e.g., freedom from "cruel and unusual punishments") would it not be possible to climb up the intentional ladder to the "bringing something about" level and derive every other right therefrom (e.g., freedom of speech, commerce, etc.)? Would it equally be possible to infer rules that aim at bringing about wrongs (e.g., freedom of assassination) since proper behavior and wrongdoing both spring from a common "urge to do something"?

Raoul Berger illustrated the gaseous state the sublimation of intention leads to with a brilliant quote from Barzun:

"[A]bstractions," wrote Jacques Barzun, "form a ladder which takes the climber into the clouds, where diagnostic differences disappear." He adds that "at a high enough rung on the ladder of abstraction, disparate things become the same: a song and a spinning top are, after all, but two ways of setting air waves in motion." Resorting to levels of generality is merely a device to escape from the bonds of the particulars. ${ }^{154}$

152. Larry Alexander \& Saikrishna Prakash, Is That English You're Speaking? Why Intention Free Interpretation is an Impossibility, 41 SAN DIEGO L. REV. 967, 995 (2004).

153. This is a standard definition for "action" in philosophy. See, e.g., Kirk Ludwig, Collective Intentional Behavior from the Standpoint of Semantics, 41 Noûs 355, 374-75 (2007) ("When I brush my teeth, I am the agent of the brushing, but I am also an agent of it. It suffices for me to be an agent of it (whether intentionally or not) that, intuitively, my doing something contributed to bringing it about"). It bears emphasizing that "bringing something about" is here intended in the broad philosophical sense that encompasses "letting something happen." See, e.g., John L. Mackie, Omnipotence, 1 SOPHIA 13, 22-23 (1962) (rejecting the distinction in the context of divine omnipotence).

154. Berger, supra note 117 , at 733 (quoting JACQUES BARZUn, A STROLL WITH WILLIAM JAMES 59, 65 (1983)). 
Qua lawyers, we are acquainted with the poetic possibilities of language. A carbophobe's attorney, for example, might contend that a State which allows for carbohydrates consumption in public inflicts on her client a "cruel and unusual punishment[]." 155 Allegedly, the client might be suffering from psychological distress at the sight of the ingestion of pasta. The point is, judges and citizens hardly accept whatever reinterpretation defendants, or their lawyers, make of rules.

We might go further in saying that democracy is exactly the tool we have invented for deciding the correct interpretation-or "conception," as Rawls would call it ${ }^{156}$ —of heavily debated concepts such as "justice" or "the common good." If democracy settles political controversies through majority vote, constitutional interpretation solves the question of the meaning of the Constitution - whose rules people seem interested in living by in a constitutional democracy - through interpretative tools. ${ }^{157}$ What democracy decides by the means of elections and deliberations in Parliaments constitutional interpretation does, for example, through historical studies and, albeit controversially, fictional reconstruction (i.e., "what would the Framers have decided, had they faced some particular case?"). ${ }^{158}$

155. U.S. CONST. amend. VIII.

156. Rawls spelled out the concept-conception distinction in addressing alternative views on justice: "it seems natural to think of the concept of justice as distinct from the various conceptions of justice and as being specified by the role which these different sets of principles, these different conceptions, have in common.” JOHN RAWLS, A THEORY OF JUSTICE 5 (rev. ed. 1999). However, Solum highlights the connection to Gallie's work. Compare Lawrence B. Solum, Legal Theory Lexicon 028: Concepts and Conceptions, Legal THeORY Blog, (Oct. 13, 2019) $\mathrm{https} / / /$ lsolum.typepad.com/legal_theory_lexicon/2004/03/legal_theory_le_1.html

[https://perma.cc/BKX9-5AX7] ("So far as I know, the concept/conception distinction originates with 'Essentially Contested Concepts,' a paper written by the philosopher Walter Bryce Gallie in 1956"), with Gallie, supra note 107, at 176 (discussing different "conceptions" of "the ways [some] game is to be played").

157. Constitutional interpretation is here intended as the ascertainment of the meaning of a particular text (i.e., the United States Constitution): "I use the word 'interpretation' to describe the process of ascertaining the meaning of, and therefore the intentions behind, a communicative act. Thus, interpretation 'just is' the ascertainment of the original intentions of the communicator." Lawson, supra note 21, at 1461 .

158. If there exists a "distinctively lawyerly" enterprise-i.e., an activity which is qualitatively proper of the sole lawyer - there is plenty of reason for arguing "hypothetical thinking" might be the one ("[R]ather than merely marshalling, channeling, and assembling the data provided by experts, the lawyer under reasonable-person originalism must also engage in an affirmative act of construction. There is a step in the process beyond explaining what the experts have found. And the lawyer is well positioned for that task. . . . Because, however, the Constitution is a legal document drafted in legal terms for legal purposes, a legal background is helpful, if not strictly indispensable, to understanding the Constitution. At the very least, a legal background is as or more important to the interpretative enterprise as is a background in history, psychology, moral theory, or any other specialized discipline"). Lawson \& Seidman, supra note 29, at 80. See also FrANK, supra note 12, at $338-52$ (stressing the role of fictions in the legal domain). 
Whenever historical instances are removed, we are in dire straits as to the meaning of abstract clauses. We would expect Dworkin to provide us with a criterion for deciding their "true" referents, but insofar as Dworkin does not provide us with a rationale for the "boiling point" at which the abstraction should stop, lest it turn into the aforementioned "sublimation of intention," 159 there is some difficulty in breaking down the content of abstract clauses. One could find an argument for denying Dworkin's reconstruction precisely in the understanding that the Framers did not want to enact any uninterpretable provision. After all, nemo tenetur ad impossibilia. ${ }^{160}$

\section{Agency and Communication}

At a philosophical level, Dworkin's sublimation of intention seems to stem from a peculiar account of how actions and communications are supposed to work.

In one respect, it is hard to square the activity of the Dworkinian framer with some commonsensical ideas about human agency. As generally conceived, an action is "intentional under some description," 161 a change of reality that points toward a result the agent is acting to reach. Negatively framed, it means that for an action to make sense, it has to be directed toward some results and not others. But in the case of the moral reading of the Eighth Amendment, what limits are there for the prescriptive content of the clause? Or, to put it slightly differently, what punishments are certainly not prohibited by the clause? Is there a device, other than personal taste and inclination, that should point to us the instances surely not covered by the clause? One may resort again to the idea of the illusions the Framers strived to implement (e.g., they were, that is, most interested in the pretense of an eternal linguistic formula, whose content judges and other interpreters would have restated at any future time). ${ }^{162}$ But if that is the case, how to make sense of several abstract provisions in the Constitution? Would it not suffice to state one single clause and let judges create other norms from one single "Spike Lee law"? The presence of a plurality of abstract clauses seems to be at odds at least with a complete overlapping in their meanings.

159. See supra Part II.B.1.

160. This is a variation of the more famous maxim "lex non cogit ad impossibilia." HERBERT Broom, A Selection of Legal MaXims 242-43 (T. \& J.W. Johnson 7th ed. 1874). Both formulations derive from Celsus's famous passage in the Digest: "Impossibilium nulla obligatio est." DIG. 50.17.185 (Celsus, Dig. 8).

161. DONALD DAVIDSON, ESSAYS ON ACTIONS AND EVENTS 50 (1980).

162. See supra Part II.B.2. 
Additionally, Dworkin's account of abstract clauses seems also to clash with some common assumptions about human communication. This is evidenced, for example, in his fictional story of a company's owner who has to fill a vacancy in one of her departments. ${ }^{163}$ For Dworkin, the situation of the abstract clauses' interpreter resembles that of the company manager. ${ }^{164}$

The owner requires the manager to fill the vacancy "with the best candidate available," adding "without winkling or nudging": "by the way, you should know that my son is a candidate for this position." 165 Dworkin asks the reader to assume a) that the owner is sincerely convinced of his son being the "best candidate," b) that the owner presumes everyone would interpret the instructions as pointing to his son as the "best candidate," and c) that the manager actually knows that the owner holds his son to be the best candidate. ${ }^{166}$

"Hire the best candidate" could plausibly have three meanings: $(\alpha)$ "hire the candidate I, the owner, would deem the best," $(\beta)$ "hire the candidate you, the manager, would deem the best," and $(\gamma)$ "hire the candidate which is in fact the best," that is, "the best" according to some objective description thereof. ${ }^{167}$ Dworkin evokes a situation where the owner is possibly dissatisfied with the manager's correct choice:

You [the owner] told her [the manager] to hire the best candidate.

And if, in her judgment, your son is not the best candidate, but someone else is, then she would be obeying your instructions by hiring that other candidate, and disobeying your instructions by hiring the candidate you intended and expected would get the job. You might-I hope you wouldn't-fire her if she obeyed your instructions in that way. But you couldn't deny that she had been faithful to your instructions, and that she would not have been faithful had she deferred to your view about the best candidate instead of her own. An agent is unfaithful to an instruction unless she aims to do what the instruction, properly interpreted, directs. ${ }^{168}$

On the surface, one may wonder why Dworkin feels the need to conjure up the firing. He has said the owner meant $\beta$ (i.e., "whoever were to be the best candidate in the manager's judgment, let he or she be hired" seems

163. See Dworkin, The Arduous Virtue, supra note 36, at 1255-56.

164. Id. at 1255 .

165. Id.

166. Id.

167. Id. at $1255-56$

168. Id. 
here the correct instruction). ${ }^{169}$ If that were the case, the owner got what he asked for. Aside from trivial plot twists, ${ }^{170}$ what Dworkin might be insinuating here is that the owner was actually meaning $\alpha .{ }^{171}$ But if so, it would be easy to object to the contradiction: Dworkin just told us that the instruction was $\beta$, and yet it was $\alpha$.

However, there is a simpler way to grapple with the example and it rests, again, on the implicit postulation of some objective notion of normative descriptions such as "the best candidate" (i.e., the owner's instruction was $\gamma){ }^{172}$ In the case of the requisites for a job at a large corporation, the normative idea of "best" seems easier to fathom than, for example, the propriety of being "cruel and unusual" for criminal punishments. Although, paradoxically enough, Dworkin's case of disagreement ultimately suggests the very opposite (i.e., that it is harder to pin down normative descriptions over some subject-matter than to discern someone's historical intent). Still, we might wonder how comparable the requisites for a job are with the decision over the true notion of a "cruel and unusual punishment[]."173

Perhaps the final lesson that can be gleaned from the excerpt is that Dworkin is hardly understandable without reference to some objective morality as self-evident as the requisites for performing a job. Although I debated Dworkin's view as a rejection of "expectation originalism," some passages hardly make sense absent the backdrop of objective moralityfor example, when he spoke of punishments that are cruel "according to the correct standards for deciding such matters."174

If that is the case, the conclusion would be that Dworkin finds his proper spot alongside metaphysical scholars of the law (i.e., scholars who postulate the existence of metaphysical moral objects) rather than strictly scientific researchers (namely, legal positivists). I am not sure whether this place might have agreed with Dworkin. ${ }^{175}$

169. “Assume, moreover, that you wouldn't have given the manager those instructions unless you were sure that it was obvious to everyone, including her, that your son was the best candidate." Id.

170. E.g., the owner fires the manager out of the disappointment of having been wrong about his son's primacy in the eye of the manager.

171. Again, we are ruling out other fanciful possibilities, e.g., a change in the owner's mind during the selection process (i.e., $\beta$ becomes $\alpha$ during the hiring phase).

172. Dworkin, The Arduous Virtue, supra note 36, at 1255-56.

173. U.S CONST. amend. VIII.

174. Dworkin, The Arduous Virtue, supra note 36, at 1252.

175. To my knowledge, Dworkin never repealed his anti-metaphysical original commitment. Speaking of his "characterization of individual rights," Dworkin originally said that "it does not suppose that rights have some special metaphysical character, and the theory defended in these essays therefore departs from older theories of rights that do rely on that supposition." DWORKIN, TAKING RIGHTS SERIOUSLY, supra note 68 , at xi-x. 


\section{The Price of Integrity}

If the critical apparatus of Dworkin's conception of abstract clauses has been outlined, we can pursue some reflections about his interpretative theory.

Were we to "make the best sense" of Dworkin's account, as he himself would put it, ${ }^{176}$ we should bear in mind that Dworkin always had two specific concerns: the fairness and the completeness - or, as he famously called it, the "integrity" of the law. ${ }^{177}$ This second element might account for the interpretation he reached.

For Dworkin, the point has always been to provide judges with guidance before every case, thus denying any sort of discretion in adjudication. ${ }^{178}$ In this respect, Dworkin's model surely happens to be "more legal" than, for example, Scalia's "faint-hearted" originalism. ${ }^{179}$ After all, Dworkin still infers the referential revision of constitutional provisions from some (possibly misleading) constitutional intent, whereas Scalia candidly admits to refusing an originalist interpretation in some extreme occurrences ${ }^{180}$ — which is a synonym, in Scalia's legal thought, with being unwilling to apply the law. ${ }^{181}$

However, the pragmatic benefits some constitutional doctrine might lead to, as well as the pretense of legality thereof, are not really the matter of contention here. Either from the point of view of a bullheaded political originalist or from the standpoint of the cognitive originalist, the only thing at stake is constitutional fidelity. ${ }^{182}$ The credibility of the psychological hypothesis underpinning some constitutional interpretation-here, the truth within the understanding that the judicial update of abstract clauses was originally set forth by the Framers - is what really matters. In this respect, if the outlined criticism seems tenable, it is hard to concede that Dworkin's theory is a feasible reconstruction of the

176. Dworkin, The Arduous Virtue, supra note 36, at 1260.

177. DWORKIN, LAW's EMPIRE, supra note 30, at 95-96.

178. See Frederick Schauer, Legal Realism Untamed, 91 TEX. L. REV. 749, 762 (2013).

179. Justice Scalia confessed that he would have not abided by an originalist interpretation in the hypothetical occurrence of a statute that reintroduced the penalty of flogging, even though it happened to be a viable punishment for the Framers: "I hasten to confess that in a crunch I may prove a faint-hearted originalist. I cannot imagine myself, any more than any other federal judge, upholding a statute that imposes the punishment of flogging." Antonin Scalia, Originalism: The Lesser Evil, 57 U. CIN. L. REV. 849, 864 (1989) [hereinafter Scalia, Lesser Evil].

180. See id.

181. Id. Insofar as Scalia considers originalism the true method of legal interpretation (i.e., the method that generates the true meaning of the law), every time he falls short of abiding by the originalist interpretation, he neglects application to the law altogether.

182. See supra text accompanying note 29 . 
Framers' intentions. Even before engaging in a detailed historical inquiry, his account proves psychologically unsound.

Dworkin's model of the constitutional change of abstract clauses may thus yield a valuable adjudicative result, ${ }^{183}$ but "at too high a price," as Hart would have it. ${ }^{184}$ In that it does not appear to comport with the rationale of a rigid constitution and with common-sense beliefs about language and communication, Dworkin's view makes more sense when seen as a revision rather than an interpretation of the Constitution's original meaning. ${ }^{185}$

\section{THE BORKEAN ORIGINALIST: ABSTRACT CLAUSES AS CONCRETE Clauses}

\section{A. The "Same Law New Law" Dilemma}

As unlikely as Dworkin's account might appear, it proves practically viable: The Supreme Court's Eighth Amendment jurisprudence clearly attests it. ${ }^{186}$ On the contrary, if a Borkean account of abstract clauses does comply with the rationale of a rigid constitution, it becomes ontologically unlikely. It has, that is, an insufficient descriptive value in regard with abstract clauses. This is the thesis I will advocate below.

First, it ought to be noted that the U.S. Constitution does not contain any amending process outside Article V, nor did the Amenders in 1791 provide any ad hoc procedure for the modification of abstract clauses. ${ }^{187}$ Ergo, we must conclude that the Framers thought Article V's provisions viable also with regards to abstract clauses (e.g., the Eighth Amendment's ban on "cruel and unusual punishments"). To the Framers, the abstractconcrete clauses distinction was, if anything, not a matter of amendment

183. Of course, assuming legality — or the pretense thereof — is a valuable objective in the law.

184. HART, supra note 142 , at 38 .

185. Or, to put it differently, this is for me the best explanation of Dworkin's discourse on abstract clauses. See generally Douven, supra note 77.

186. See supra text accompanying note 109 (quoting some representative passages within this jurisprudence). See infra Part IV.A (discussing Justice Warren's most famous maxim on the Cruel and Unusual Punishments Clause).

187. The seemingly exclusive nature of Article $\mathrm{V}$ formal procedure remains one of the most important arguments against judicial revisionism. See Brest, supra note 49, at 236 (acknowledging the "availability of the amendment process" as a problem for nonoriginalist theories of adjudication). Contra ERWIN CHEMERINSKY, INTERPRETING THE CONSTITUTION 66 (1987) (arguing that judicial amending of the Constitution is nonredundant since formal amendment has the unique capability of reversing Supreme Court decisions, changing the Constitution in parts that it would hardly undergo judicial scrutiny, and providing "symbolic reinforcement" of the new constitutional doctrines). 
procedure. As to the Borkean amending standpoint, all clauses are concrete. $^{188}$

The problem with a "Borkean" account of abstract clauses lies within its result: It leads to a theoretically viable outcome that has, nonetheless, never taken place in reality. Following the Borkean approach brings the interpreter to a paradoxical expectation about how the amendment of abstract clauses should unfold. Some could even have a hard time calling this kind of legal change an "amendment" at all. I shall call this phenomenon the "same law, new law" dilemma.

Let us consider a Borkean originalist interpreter, who conceives of every constitutional clause as a concrete one and therefore submits it to the procedures set out in Article V. ${ }^{189}$ With regard to the Eighth Amendment, for example, the originalist would hold the prohibition of "cruel and unusual punishments" to have a fixed "referential scope." 190 The provision refers to only some specific historical instances of "cruel and unusual punishments." ${ }^{\text {"191 }}$ The clause cannot be stretched to encompass cases of punishments that may be considered cruel and unusual today but were not regarded as such at the enactment's time. The converse also follows: The clause outlaws punishments that were once considered cruel and unusual, even though they may not be perceived so today. In the Borkean originalist's view, the Cruel and Unusual Punishments Clause refers to nothing but some specific examples at the time of the Amendment's drafting.

As time passes, what is socially considered cruel by the people changes and the need for an adjustment of the clause's referential scope to current social perceptions may arise. ${ }^{192}$ New instances of cruelty emerge, while old paradigmatic cases are not considered proscribed punishments anymore. ${ }^{193}$ The clause's reference needs to be updated.

Let us imagine that the Government funds a trustworthy survey on the citizens' current opinions on the death penalty. Assume that the survey clearly states that the killing of a person perpetrated by the State is

188. For the distinction see supra Part I.

189. See supra Part I.B. ๆ 6.

190. I am employing "referential scope" as a synonym for the aforementioned "referential content." See supra text accompanying note 60 .

191. For simplicity's sake, this Article does not tackle the distinction between "original public meaning" originalism and "original intent originalism." See Whittington, supra note 50, at 379-86. I simply adopt the stance of those who dismiss the factual relevance of distinction. See, e.g., Lawrence B. Solum, Intellectual History As Constitutional Theory, 101 VA. L. REV. 1111, 1136 (2015) (arguing for the fundamental consistency of the two approaches).

192. That the societal understanding of what makes for a "cruel and unusual punishment" changes is unquestioned. See infra Part III.A. \ๆ 11-12.

193. See infra Part III.A. १ฯ 11-12. 
regarded as a cruel punishment by the absolute majority of U.S. citizens. The Borkean originalist cannot hold the death penalty unconstitutional since many States retained it in 1791, and no signs of an abolitionist intention were given at the time. ${ }^{194}$ Nonetheless, she rebuffs the idea that the Framers requested her to perform any kind of Dworkinian "moral judgment." Being loyal to the clause means holding unconstitutional what was regarded as a "cruel and unusual punishment" either by the Framers or by a "reasonable person" of that time. ${ }^{195}$ The legislature might ask the originalist how it is possible to adapt the Constitution to the current societal conception of a "cruel and unusual punishment." The originalist would retort that an amendment pursuant to Article $\mathrm{V}$ has to take place. No way out.

A shortcut solution would be to add the following words to the Eighth Amendment: "the death penalty is a cruel and unusual punishment" or "the death penalty is forbidden." It seems indeed reasonable that such a momentous change would make its way into constitutional wording.

Now, let us suppose that the survey had incidentally discovered that $a$ lot of other changes have occurred where punishments were held cruel and unusual by the majority of the American citizens, when compared to the Eighth Amendment occurrences. The originalist could collect each of those variations and list them out in the new clause, thus determining what has to be considered cruel and unusual now.

The problem is that the "itemizing approach" seems a toilsome and unnecessary task. It is toilsome because many punishments once held humane and usual might now be perceived cruel and unusual; or, albeit less likely, instances of cruelty and unusualness might not be regarded that way anymore. Additionally, the notion of "punishment" itself can undergo relevant referential modifications. ${ }^{196}$ But most importantly, creating an "inventory of cruelties and unusualness" is not only a complicated task but a rather unnecessary one, as the phrase "nor cruel and unusual punishments [be] inflicted" 197 would still perfectly generate the outcome

194. See Baze v. Rees, 553 U.S. 35, 87-88 (2008) (Scalia, J., concurring). at 1 .

195. Scalia, Common-Law, supra note 50, at 17. See also Lawson \& Seidman, supra note 29,

196. To some extent, every behavior that is enforced through public force can be subjectively perceived as punishment for something. Consider, for example, compulsory vaccination, which is traditionally not even considered a "punishment," but that anti-vaxxers (a movement of people primarily in western countries who refuse vaccines for themselves and their families) might arguably contend to be a "cruel and unusual" one. Cf. Erwin Chemerinsky \& Michele Goodwin, Compulsory Vaccination Laws Are Constitutional, 110 Nw. U. L. REv. 589, 609 (2016) (arguing for the legitimacy of compulsory vaccination that does not instantiate a "punishment" for a particular religious group).

197. U.S. CONST. amend. VIII. 
the amending legislature aims to achieve. Words, as it were, are still functional to the intention. It is only a matter of time-reference.

Let us assume our Borkean originalist is a word-thrift, one that does not change the words' arrangement if it proves viable for the intention she wants to convey. ${ }^{198}$ She may ask herself: "Do I need, linguistically, to change the Formula?" The answer is surely negative: Linguistically, the words of the Cruel and Unusual Punishments Clause are still perfectly apt. The Borkean originalist needs only to change the time-reference. ${ }^{199}$

Her final decision, then, would be to re-enact the words of the Eighth Amendment as they are now through Article V's procedures. Paradoxical as it may sound, she would achieve her goal in doing so. The clause's normative reference would shift to current times, while words remain the same: The provision displays the same string of words but with a $t$-value changed to today. On the grounds of the assumed consensus about the death penalty and other instances of "cruel and unusual punishments," the re-enacted Eighth Amendment would address the people's requests without employing any grammatical change. Same law, new law.

This procedure is not only possible but mandatory for any nonDworkinian originalist. It is the only formal way to amend the abstract clauses of the Constitution for the "economic" Borkean originalist (i.e., the originalist who does not change the words of the clause if they are still fit for the prescription she wants to enact). The re-enactment of the same words of the original Eighth Amendment through Article V's procedures ought to take place.

I do not think one can disagree with this scenario from a theoretical (i.e., a priori) point of view: It might actually work out. It is a thinkable "state of affairs." 200 The problem with this re-enactment procedure is its "positive" status: this way of amending the Constitution has never taken place in the history of American law. ${ }^{201}$ Probably, it has never happened

198. There is a historical consensus against lengthy enumerations of rights in the constitutional text. While commenting on the incorporation of the Civil Rights Act in the Fourteenth Amendment, Bickel stated:

To all this should be added the fact that while the Joint Committee's rejection of the civil rights formula is quite manifest, there is implicit also in its choice of language a rejectionpresumably as inappropriate in a constitutional provision - of such a specific and exclusive enumeration of rights as appeared in section 1 of the Civil Rights Act.

Alexander M. Bickel, The Original Understanding and the Segregation Decision, 69 HARV. L. REV. 1, 61 (1955).

199. The $t$ value in the formal model. See supra Part I.B.

200. WitTGENSTEIn, TRACTATUS, supra note 98, at 12.

201. A related and more commonly debated phenomenon is the meaning of the Due Process Clause as differently enacted in the Fifth and Fourteenth Amendment. See Ryan C. Williams, The One and Only Substantive Due Process Clause, 120 YALE L.J. 408, 498-500 (2010) (arguing that the Fourteenth Amendment Due Process Clause may retain a substantive content the Fifth Amendment 
throughout the entire history of law. No state, no legislature, no king-to my knowledge - has ever replaced a rule with a new rule displaying the same string of words and pretended to have changed anything in the law. In this sense, "same law" has arguably never been considered "new law." We might even feel awkward in calling such a piece of legislation an "amendment," even if aware of the time-reference shift.

At the same time, it is hardly believable that the societal conception of a "cruel and unusual punishment" has not changed over time. Surely it is an empirical assessment, one that has to be evaluated through surveys and studies, but I would say it is a fairly agreeable one. In fact, it seems to be the only point the Supreme Court's "Dworkinian" Evolving Standards doctrine and Scalia's "Borkean interpretation" agree upon, since they are both premised on the very fact that a change in the societal conception of "cruel and unusual punishments" has taken place. ${ }^{202}$ They simply disagree on the inferences therefrom. ${ }^{203}$

\section{B. A Cramped View on Legal Concepts?}

Before offering my solution to the problem raised by abstract clauses, it is useful to confront a possible objection arising from the use of the concept of "referential content of a rule." 204 In fact, the "same law new law" dilemma (i.e., the need for re-enacting the same words in order to

does not contain). The relevant difference between that instance and the "same law new law" problem is that there was a broader rationale for enacting the Fourteenth Amendment-namely, to extend the Due Process Clause to states and local governments. However, the re-enactment of the same formula wound up absorbing the substantive meaning of the Due Process Clause. By contrast, in the case of the "same law new law" dilemma, the re-enactment of the same provisions is necessitated by nothing but the referential change.

202. Compare Scalia, Lesser Evil, supra note 179, at 861 (holding flogging and handbranding as punishments that are inconsistent with today's current standards), with Dworkin, The Arduous Virtue, supra note 36, at 1253 (discussing the conceptions of Framers on what punishments were indeed cruel and unusual).

203. If interpreted as postulating the existence of some "objective morality" similar to mathematics, Dworkin's position is plainer and somehow more coherent. See DWORKIN, RELIGION WiTHOUT GOD, supra note 96; Dworkin, The Arduous Virtue, supra note 36, at 1252 ("the correct standards for deciding such matters-cruel"). In this case, if there obtains a strife between today's conception of "cruel and unusual punishments" and the Framers" one, it "simply" means that either the current citizens or the Framers are mistaken in their concept of what a cruel and unusual punishment is (i.e., someone is doing the math wrong). Scalia's interpretative account, nonetheless, might turn out metaphysically less-demanding, if one had a hard time accommodating the idea of some objective morality whose truth-value and computation should resemble those of mathematics. Besides, it was Scalia's adjudicative account (i.e., the fact that he claimed he would have used his interpretative account in some occurrences) that stirred controversy, not his interpretation. See Scalia, Lesser Evil, supra note 179, at 864. See generally Jack M. Balkin, Abortion and Original Meaning, 24 CONST. Comment. 291 (2007); Randy E. Barnett, Scalia's Infidelity: A Critique of "Faint-Hearted" Originalism, 75 U. CIN. L. REV. 7 (2006) (criticizing Scalia's account).

204. I thank Gary Lawson for pointing out this possible shortcoming in my account. 
update the referents of the expression ${ }^{205}$ ) might be mandatory only insofar as one is clinging to a limited view about how concepts and meanings work.

In recent times, Gary Lawson and Tara Smith have raised the question of the troubled relationship between originalism and the philosophical nature of concepts. ${ }^{206}$ Despite reaching different conclusions, they both build upon Ayn Rand's "objectivist" theory of concepts. ${ }^{207}$ Smith, in particular, reaches the worrisome conclusion that "Originalism fails to appreciate ... that the language of the law, like all language (apart from proper names), is conceptual.",208

What are originalists getting wrong about language and concepts? The main problem seems to be that at least some kind of originalism confuses the "referents" of the clause with the "criteria for determining the referents," ${ }^{209}$ or, to put it slightly differently, it fails to grasp the "openended nature of concepts." ${ }^{210}$ The problem is most apparent in the case of technological development. ${ }^{211}$ If originalists believe that interpreting the Free Speech Clause means to grant protection only to the referents that were contemplated by the Framers, surely e-mails, for example, could not receive constitutional protection as they could not fit into the Framers' or the public reader's possible understanding of the clause in 1791. However, to interpret the clause in this sense would be a huge mistake, as the Framers arguably did not want to limit the clause's meaning to what individuals believed at the time. Instead, what they identified are the "criteria for determining the referents": ${ }^{212}$ that is, in the example, every possible means that conveys "free speech."

205. See supra Part III.A.

206. Lawson, supra note 21, at 1469-70 (warning against the conflation of the "criteria for determining the referents" with the historical referents); Tara Smith, Originalism's Misplaced Fidelity: "Original" Meaning Is Not Objective, 26 CONST. COMMENT. 1 (2009) (arguing that originalists fail to grasp the "objective meaning" of words).

207. Ayn RAND, IntRoduction to OBJectivist EPISTEMOlogy (Harry Binswanger \& Leonard Peikoff eds., 2d ed. 1990).

208. Smith, supra note 206, at 28.

209. Lawson, supra note 21, at 1469.

210. Smith, supra note 206, at 56.

211. " $[\mathrm{H}]$ ow do we apply the fixed text of the Constitution, a document that is more than 200 years old, to cases involving electricity, credit cards, the Internet, cell phones - scenarios that not only did not exist at the time the Constitution was ratified, but could not have been envisioned by the framers of the Constitution?" Levine, supra note 121, at 752.

212. Gary Lawson weighs the concept of liberty under the Fifth Amendment instead of the Free Speech Clause ("An empirical reader would not ask for a laundry list of specific human activities that exhaust the content of the concept. But an empirical reader would ask what criteria the author, and derivatively the public reader, had in mind for distinguishing things that fall into that author's/reader's concept of 'liberty' from other things that are better organized-from the cognitive standpoint of the author/reader - under other conceptual headings"). Lawson, supra note 21, at 1470. 
Besides the fact that hardly any originalist ever entertained such a view, ${ }^{213}$ this issue seems to have little bearing on the interpretation of the Cruel and Unusual Punishments Clause. The Borkean originalist, in fact, does not read the clause as though it referred only to the particular subjective instances of a punishment that were "cruel and unusual" for the public reader at the time (i.e., new punishments might have hurt her sense of cruelty at the time and should thus be held unconstitutional). In this sense, she surely holds the "criteria for determining the reference" to be part of the original meaning: What is locked to the original meaning of the clause is the normative understanding of cruelty and usualness as conceived by the original interpreters. For the Borkean originalist, the Clause can qualify as constitutional or unconstitutional punishments that could never arose in the minds of the original interpreters. But the criteria that must be used in constitutional review are the original senses of cruelty and usualness - not today's, as the Dworkinian originalist would conversely maintain. ${ }^{214}$

If the similarly highly subjective concept of "beauty" were entailed, for example, the Borkean originalist could certainly apply it to facts the Framers never could have encountered, but the standard of "beauty" that will make up for the judgment of cruelty and usualness would be the Framers', not her personal one. ${ }^{215}$ As Bork clearly stated in a different context, "[i]n a case like this, it is the task of the judge in this generation to discern how the Framers' values, defined in the context of the world they knew, apply to the world we know. The world changes in which unchanging values find their application." 216

In other words, the Dworkinian and the Borkean originalist are still performing two quite different operations when applying the Eighth Amendment, whatever theory of concepts one is to retain. The Borkean

213. Originalists consistently argue for the extension of free speech guarantees to modern communication devices. See, e.g., Scalia, Common-Law, supra note 50, at 38 (arguing that "speech" and "press" work as a synecdoche for different types of communication); Nelson Lund, Living Originalism: The Magical Mystery Tour, 3 TEX. A\&M L. REV. 31, 34 (2015) (claiming that the Free Speech Clause applies to the internet); Lawrence B. Solum, Construction and Constraint: Discussion of Living Originalism, 7 JRSLM REV. LEGAL. STUD. 17, 21 (2013) (arguing in favor the originalist protection of the internet in virtue of the "semantic content" of the freedom of speech); Steven G. Calabresi, On Originalism and Liberty, 2015-2016 CATO SuP. CT. REV. 17, 29 (2015-2016) (resorting to Scalia's image of the synecdoche). See generally Lee J. Strang, Originalism and the "Challenge of Change": Abduced-Principle Originalism and Other Mechanisms by Which Originalism Sufficiently Accommodates Changed Social Conditions, 60 HASTINGS L.J. 927 (2009) (claiming that originalism has the interpretative tools for facing, among others, technological change).

214. See supra Part II.

68.

215. The same holds, e.g., with the concept of "work of art." Gallie, supra note 107, at 167-

216. Ollman v. Evans, 750 F.2d 970, 995 (D.C. Cir. 1984) (Bork, J., concurring). 
originalist will confront some punishment with "the Framers' values."217 The Dworkinian, conversely, is going to compare the punishment under evaluation with current societal perceptions. ${ }^{218}$ In this sense, their divergence is truly interpretative, not philosophical: The Borkean contends that the Framers meant to hitch the Clause to their standards of cruelty and unusualness; the Dworkinian holds that the Framers referred to every future generations' understanding of the cruelty and unusualness of punishments.

\section{A BREACH IN THE FORMAL CONSTITUTION}

If the aforementioned "same law" procedure is the only formal way a loyal, Borkean originalist can amend the Constitution, and if there had been changes in the societal idea of what a "cruel and unusual punishment" amounts to, how is it possible that the nobody has demanded that the clause be amended? Is it necessary to impute this outcome to the Supreme Court's choice for some Dworkinian approach instead of a Borkean one? Or is there another possibility to conceive of this apparent strangeness?

\section{A. Partially Jettisoning Formalism}

Tertium datur: I stand for the third possibility. My answer to the dilemma is the simplest one: the best way to make sense of the amendment of abstract clauses is to conclude that it does not conform to formal legal reasoning. Instead, it is a plain instance of informal (i.e., non-legal) change. But if that is the case, the law is nonoriginalist (i.e., it does not comport with the original intent or public meaning) ${ }^{219}$ in this instance.

As attempts to subsume this type of legal change under formal legal reasoning, both the Dworkinian and Borkean views fail. While the former appears psychologically unlikely, the latter turns out counterfactual and hardly believable, although theoretically viable. An originalist account such as the Borkean reconstruction, in particular, has insufficient "explanatory value" as it cannot hold the factual legal change of abstract

217. Id.

218. See supra Part I.B.

219. I do not dwell here on the distinction between the epistemic object that performs the interpretative work in different originalist theories. Despite the long-standing opposition between original intent and original meaning, modern scholars dispute the significance of the actual objects that "bind" the meaning of the clause. See Lawrence B. Solum, Intellectual History as Constitutional Theory, 101 VA. L. REV. 1111, 1136 (2015) (arguing that cases of divergence between original intent and public meaning originalism are unlikely); Berman, supra note 29, at 9-10 (slighting the importance of distinguishing originalisms in light of the object that does the epistemological work). 
clauses legitimate - in that it does comport with the procedures of Article $\mathrm{V}$ - but at the same time it does not call for the "same law new law" amending procedure.

The good news, however, lies in the fact that the destiny of legal inquiry is not necessarily bound to the one of formal legal change. On the contrary, I believe that we are better off when we cease trying to cram this occurrence into any formal account. Legal realism, as will be shown, can help us in making sense of the phenomenon of "informal legal change."220

Formalism is an important, and yet nonexclusive option when we deal with legal phenomena. ${ }^{221}$ It is generally a viable solution (even, as I tried to demonstrate, in the extreme case of abstract clauses!). Moreover, formalism is also frequently a reliable description of reality, as one can easily guess from the outstanding frequency of either compliance with the law, or punishment of trespassers. Even when legal rules are neither obeyed nor enforced, it is possible to explain the unpunished breaches in terms of the practical limits of the State's repressive power. In sum, originalism and formalism are still arguably the go-to interpretations for legal phenomena. ${ }^{222}$

But this might not always be the case, as the referential change of abstract clauses suggests. The limits of the Dworkinian and Borkean solutions thwart any attempt of encompassing this kind of legal change into a formalistic account. In this respect, it is possible to subscribe to Strauss's remarks: "Although formalism has its advantages and functionalism its dangers, the former is simply incapable of describing the government we have." 223

We may wonder why this should be so. The answer is indeed obvious if we accept a simple idea of psychic equilibrium, under which every action has a tradeoff: ${ }^{24}$ sometimes the costs of some traditionally performed

220. Of which "informal constitutional change" is obviously a subset. See supra note 10.

221. See infra Part V.B.

222 It bears noting that the validity of a formalist/originalist account for the broadest part of the law is actually consistent with the realist approach. Although the realists had often been regarded as unbridled rules-skeptics, they were frankly quite modest in their statements. They confined their skepticism toward rules to the range of cases that rose to the level of litigation, thus saving commonsense formalism - and I would add originalism - as the true descriptive account in undisputed applications of the law (e.g., mere compliance with the law). See supra note 17.

223. Peter L. Strauss, Formal and Functional Approaches to Separation-of-Powers Questions - A Foolish Inconsistency?, 72 CORNELL L. REV. 488, 526 (1987) (emphasis added).

224. I am implicitly thinking of Freud's "scientific psychology." See Sigmund Freud, Project for a Scientific Psychology, in THE ORIGINS OF PSYCHO-ANALYSIS 347-445 (Marie Bonaparte, Anna Freud \& Ernst Kris eds., Eric Mosbacher \& James Strachey trans., Basic Books 1954). See generally Lawrence Birken, Freud's "Economic Hypothesis": From Homo Oeconomicus to Homo Sexualis, 56 AM. IMAGO 311 (1999) (describing the foundations of Freud's psychic economics and its ties with physics). 
action (i.e., formal/originalist application of the law) might outweigh its benefits. While playing by the rules - or punishing the transgressors, or ascribing the absence of punishment to the pragmatic limits of public force - is a choice whose social benefits generally outweigh enduring lengthy formal procedures, in the case of abstract clauses things might be the other way around. Here, formalism must strike as a (psychologically) costly solution, and compliance with entrenched rules is abandoned. This explains the lack of demands that a legislature re-enact a linguistically identical rule simply to update its referential content. In the case of the Eighth Amendment's Cruel and Unusual Punishments Clause, U.S. citizens short-circuit Article V's procedure by consenting to judicial legal amending, in spite of its formal "illegality" (i.e., the property of lying outside of the original interpretation of the Constitution). The proof of this consent is to be found in the absence of any demand for a formal amendment of the clause, despite the modifications occurring within the notion of a "cruel and unusual punishment."225

Qua strict adherence to "paper rules," 226 formalism is a human value, and as every value it provides benefits at a price. ${ }^{227}$ Formalism enables human beings to rely on institutions and to conform their behavior to rules by fostering legal certainty. ${ }^{228}$ Just as language does not operate in the idiosyncratic manner of Lewis Carroll's Humpty Dumpty if mutual

225. However, inferring consent from tacit behavior remains controversial. See, e.g., KeITH E. WhitTington, CONSTITUTIONAL INTERPRETATION: TEXTUAL MEANing, ORIGINAL INTENT, AND JUDICIAL REVIEW 130-31 (1999) (criticizing theories of consensual government based on tacit consent of the governed).

226. Karl N. Llewellyn, A Realistic Jurisprudence: The Next Step, 30 Colum. L. REV. 431, 444-57 (1930).

227. A refusal to acknowledge the natural value of formalism is what really undermines some reconstruction thereof. See, e.g., Strauss, supra note 223, at 526 ("At best formalism serves as proxy for a functional approach for Justices perhaps unwilling to trust their inheritors - or even themselveswith the difficult and contextual analyses that functionalism requires"). Formalism cannot be reduced to a "proxy" for future (untrustworthy) functionalist judges: It displays a daily value in legal relations, even before any adjudication is needed. See Schauer, supra note 41, at 510 (stating "[f]ormalism is the way in which rules achieve their 'ruleness' precisely by doing what is supposed to be the failing of formalism: screening off from a decisionmaker factors that a sensitive decisionmaker would otherwise take into account. Moreover, it appears that this screening off takes place largely through the force of the language in which rules are written. Thus the tasks performed by rules are tasks for which the primary tool is the specific linguistic formulation of a rule. As a result, insofar as formalism is frequently condemned as excessive reliance on the language of a rule, it is the very idea of decisionmaking [sic] by rule that is being condemned...."). Are we really to deny the practical value of "decisionmaking by rule"?

228. See Daniel A. Farber, The Inevitability of Practical Reason: Statutes, Formalism, and the Rule of Law, 45 VAND. L. REV. 533, 542-43 (1992) (outlining, although critically, the certainty argument in favor of formalism). 
communication is to bear fruit, a certain degree of formalism is necessary in order for the law to be a successful enterprise. ${ }^{229}$

But formalism is not always the psychically economic choice, as we can infer from the legal change of abstract clauses. ${ }^{230}$ It has its drawbacks, its "psychological costs" - one possibly being the hindrance of the law's prompt adaptation to societal changes. In the case of abstract clauses, legal formalism amounts to an unbearable blockade to legal change. Its purpose, its "raison d'être" 231 becomes an unbearable burden. If the cost of formal compliance greatly outweighs the benefits - as in the "same law new law" fictitious example - citizens let go of formal strictures: They trade the certainty value provided by formal amendments with the smoothness, easiness, and day-by-day actualization of judicial update. To say it with Bork: In this case, "good results" trumps "legitimate process.",232

The balancing of formalism and nonformalism can be conceived as a matter of psychic equilibrium: Every time the level of formalism is exceedingly severe, people dampen its effects by consenting to some kind of judicial activism. ${ }^{233}$

While easy and agile, informal legal change arguably comes at some costs. Besides the potential loss in legal uniformity, empowering judges with the ability to reshape a clause's content opens the way for judicial misuses (i.e., the manipulation of the clause's content so that it does not match the citizens' general ideas, but rather the personal tastes and moral convictions of the judges). ${ }^{234}$ Again, when legal uncertainty and judicial

229. Humpty Dumpty is the hilarious character from Alice in Wonderland, who famously conceived of the meaning of words as the one the utterer would give to them. See LEWIS CARROLL, Through the Looking Glass, AND What Alice Found There 185-97 (Peter Hunt ed., Oxford Univ. Press 2002).

230. See supra Part III.A.

231. That is, to arrange legal change into a fixed, verifiable procedure.

232. BORK, TEMPTING, supra note 54, at 261-65.

233. The idea that formalism retains also desirable aspects secularly reflects Frank's opposite considerations on the benefits of legal uncertainty: "Much of the uncertainty of law is not an unfortunate accident: it is of immense social value." FRANK, supra note 12, at 7.

234. According to Bork,

Those who now dominate public discourse on these matters recognize that, if the Constitution is law, departures from the principles the ratifiers understood themselves to be enacting are illegitimate. Yet such departures are essential if the results desired by the liberal culture are to be achieved through the courts. It follows that the Constitution cannot be law. Thus, the morality and politics of the intellectual or knowledge class, a class that extends well beyond the universities, can be made into constitutional law. . . .

Judges are by definition members of the intellectual class and, in addition, for professional and personal reasons, tend to be influenced by the culture of the law schools. . . . If they can be persuaded to abandon the idea of original understanding, they are quite likely to frame the constitutional rules that reflect the assumptions of modern liberal culture.

BORK, TEMPTING, supra note 54 , at 8. 
misuses raise to an unbearable pitch for a sufficient number of citizens, reverse phenomena are supposed to obtain, and a major dose of formalism is poured back into the legal system (e.g., through legislative introduction of stricter entrenched procedures, or academic literature that demands for higher compliance with the formal legal processes). ${ }^{235}$ Whit this readjustment, the legal system goes back to balance.

In a sense, political originalism can be seen as nothing but a physiological response to the pervasiveness of judicial activism. It is the law-organism's reaction against biological dissolution. I would even go further in saying that, to a certain extent, an allegedly neutral research agenda is perhaps hardly neutral as it is pursued at a specific moment in legal history. ${ }^{236}$

I think Justice Scalia's candid openness to a nonoriginalist application of the Eighth Amendment comports with this acknowledgment of the limited value of legal formalism. ${ }^{237}$ In the case of the Eighth Amendment, an originalist analysis might dictate a certain result but that does not imply, per se, that it will be the chosen one: for formalism lies in competition with other values (most significantly, the desirability of

235. This utilitarian conception of formalism is captured by Horwitz, although in excessively political terms:

If a flexible, instrumental conception of law was necessary to promote the transformation of the post-revolutionary American legal system, it was no longer needed once the major beneficiaries of that transformation had obtained the bulk of their objectives. Indeed, once successful, those groups could only benefit if both the recent origins and the foundations in policy and group self-interest of all newly established legal doctrines could be disguised. There were, in short, major advantages in creating an intellectual system which gave common law rules the appearance of being self-contained, apolitical, and inexorable, and which, by making 'legal reasoning seem like mathematics,' conveyed 'an air . . . of . . . inevitability' about legal decisions."

Morton J. Horwitz, The Rise of Legal Formalism, 19 AM. J. LEGAL HIST. 251, 252 (1975) (first quoting Oliver Wendell Holmes, Privilege, Malice and Intent, 8 HARV. L. REV. 1,7 (1894) then quoting KARL N. LLEWELLYN, THE COMMON LAW TRADITION: DECIDING APPEALS 38 (1960)).

236. For what I mean by "political originalism," see supra note 29. The remark goes somewhat against the claim of neutrality I affirm for the inquiry. I would rejoin, however, that there exists at least a meaningful sense in which producing scholarship with the intention of achieving political results is different from doing research for the sake of understanding phenomenon and forecasting future developments, despite any political relevance "neutral scholarship" could possibly assume. The difference rests in the (conscious) intentionality of the political effects.

237. See Scalia, Lesser Evil, supra note 179. It is easy, however, for living originalists to indict the view for cherry-picking ("[U]nder this approach, not all of the incorrect precedents receive equal deference. Judges will inevitably pick and choose which decisions they will retain and which they will discard based on pragmatic judgments about when reliance is real, substantial, justified or otherwise appropriate... This play in the joints allows expectations-based originalism to track particular political agendas and allows judges to impose their political ideology on the law-the very thing that the methodology purports to avoid"). Balkin, supra note 203, at 298-99. 
results). ${ }^{238}$ This is also why Lawson and Seidman describe what I called "political originalism" (i.e., the political claim that the Constitution be interpreted in an originalist fashion) as an issue for "political moralists": 239 for cognitive originalism does not entail political originalism. ${ }^{240}$ This conclusion would incidentally agree with one of legal positivism's main motifs: that "the certification of something as legally valid is not conclusive of the question of obedience." 241 This might be an interesting convergence for the grounding of originalism into positivism. ${ }^{242}$

Albeit arguably a misinterpretation, this is also why I find Justice Warren's use of the verb "must" ${ }^{\text {"43 }}$ in his famous formulation of the Eighth Amendment jurisprudence illuminating: "The Amendment must draw its meaning from the evolving standards of decency that mark the progress of a maturing society." 244 The "must" could read not as an interpretative necessity ${ }^{245}$ (i.e., "the Framers wanted it to be read as if it entailed this evolving aspect") but as a practical maxim. ${ }^{246}$

It bears emphasizing that this devaluation of legal formalism is hardly a new or startling thought in the law. It is rather the reaffirmation of an old truth. From Antigone's rebellion to the "decrees" 247 of the ruler on the grounds of the obedience to the "unwritten and unfailing statues of heaven," ${ }^{448}$ to Aquinas's maxim "an unjust law is not a law," ${ }^{249}$ several

238. "Good results," as opposed to "legitimate process." BORK, TEMPTING, supra note 54, at 261-65. A famous example of "good results" that can hardly be squared with originalist adjudication is Brown v. Board of Education. See Michael W. McConnell, The Originalist Case for Brown v. Board of Education, 19 HARV. J.L. \& PUB. POL'Y 457, 457 (1995) (acknowledging the overwhelming consensus that originalism cannot support Brown).

239. Lawson \& Seidman, supra note 29 , at 53.

240. Id.

241. HART, supra note 142 , at 210 . The reference to Hart raises, however, another question: Are the non-legal determinants that come into play where legal rules do not obtain to be included in the concept of "law"? This is exactly the type of conceptual theorizing that Leiter considers viable even in a post-Realists world. See LeITER, NATURALIZING JURISPRUDENCE, supra note 2, at 45. I would argue that there is little epistemic benefit in stretching the notion of law outside the "fairly crude type of legal positivism" the Realist seemed to retain. See id. But surely more argumentation would be needed here if my concurrence were not to boil down to a mere fiat.

242. See William Baude \& Stephen E. Sachs, Grounding Originalism, 113 Nw. U. L. REV. 1455 (2019) (advocating originalism as the dominant interpretative practice in American law).

243. Trop v. Dulles, 365 U.S. 86, 101 (1958).

244. Id. (emphasis added).

245. This would be the case if the Framers intended the Eighth Amendment to be read as if entailing this "evolving capacity." Contra supra Part II.

246. The practical maxim consists of acknowledging that the original meaning could be different, but nonetheless claiming that we must (i.e., for practical reasons) interpret the clause as if it entailed the evolving mechanism even though we are giving up on original meaning in doing so.

247. 3 SOPHOCles: THE Plays AND FRAGMENTS 88-89 (Richard C. Jebb ed., trans. 1885).

248. Id. at $88-91$.

249. This is the English translation of the traditional adage "lex iniusta non est lex." See Norman Kretzmann, Lex Iniusta Non est Lex: Laws on Trial in Aquinas' Court of Conscience, 
well-known individuals have claimed the existence of instances where the obedience to the law yields to the loyalty to other normative domains: ${ }^{250}$ the law of the gods, the idea of justice, etc. But while these cases raised debate and controversy, the peculiarity of the abstract clauses' case rests in its incontestability: Hardly anybody has ever demanded an application of the law similar to the one suggested by the "same law new law" experiment. No "crazy formalist," as it were, has ever claimed that U.S. citizens abide by this awkward amending procedure. Whereas both in the case of Antigone and Aquinas the antagonist formalists' claims seemed at least worth considering.

It also bears mentioning that, in denying that the dyad originalism/formalism descriptively accounts for the legal change and application of abstract clauses, I am clearly assuming an "exclusivist" version of originalism, different, that is, from the one William Baude has recently proposed when raising the descriptive dilemma: "Is originalism our law?"251 The reason is that Baude's "inclusive version of originalism"252 -if considered as an "interpretation" of the Constitution ${ }^{253}$ - seems affected by the very same issues that afflict Dworkin's "moral reading," as it allows for some "evolving construction of broad or vague language." ${ }^{254}$ The only way, that is, to accommodate Baude's "evolving construction" of abstract clauses within an originalist

33 AM. J. JURIS. 99, 100-01 (1988) (discussing different versions and attributions). As Kretzmann notes, Aquinas' quote of Augustine is actually different, as is Augustine's original passage:

"An unjust law is not a law," quoted by British and American writers almost as often in Latin:

"Lex iniusta non est lex." I haven't seen this non-est-lex slogan in Augustine or Aquinas in just those words, and I don't know who coined it. But the tradition of the controversy makes it convenient to adopt non est lex as the standard expression of the dismissive judgment regarding a law. Id. at 101 .

250. See also Radbruch, supra note 49.

251. Baude, supra note 5, at 2351 (evaluating originalism from the prospective of positive law).

252. "[A] version that allows for some precedent, for some evolving construction of broad or vague language." $I d$. at 2352 .

253. It may be debatable whether Baude's notion of "originalism" is in fact an interpretation of the Constitution (i.e., an "ascertainment of meaning,") rather than a normative proposal about adjudication (i.e., a practical proposal about what judges and other legal subjects should do with what the Constitution says). In fact, Baude's originalism comprises (i.e., considers constitutionally legitimate) the referential developments of "evolving terms" (e.g., "the words "cruel and unusual"), the "devices for resolving ambiguity or vagueness" (e.g., "construction" or "liquidation") and the rule of stare decisis. Id. at 2356-61. The problem is, either these legal doctrines are legitimate because the Constitution says so - and that is a "true" interpretative problem —or Baude's originalism is not an interpretation of the Constitution but rather a pragmatic approach toward its use. For the purpose of discussion, I am weighing Baude's arguments as if they were entailed by the original meaning of the Constitution, and not some "ameliorated understanding" thereof.

254. Id. at 2353 . 
interpretation of the Constitution is to accede to a Dworkinian point of view and contend that the Framers actually called for the "evolving construction" to take place. If my exposition of Dworkin's problems was sound, this possibility should be ruled out. ${ }^{255}$

But if the Dworkinian interpretation is not viable, the only way to square originalism with "some evolving construction" of the Constitution is to lessen the epistemological constraints of the word "originalism," so that it does not merely denote the meaning of the Constitution as intended by its authors - be they the Framers, the adopters, a reasonable reader at the time, etc.- - but the revised meaning that results from interpreting some parts of the Constitution not as they were intended to be (e.g., in accord with the evolved meaning of the same words). ${ }^{256}$

If that is the case, however, as Lawson elegantly puts it, "it is not clear that the label 'originalist' is doing a lot of useful epistemological work."257 Whenever "originalism" is used to propose something different from the original meaning of the Constitution, confusion arguably arises. ${ }^{258}$ Then either "old school" originalists ought to flee the notion of originalism - as Lawson seems to have done with his "empirical reading",59 — or those who are interested in the something other than the "ascertainment of meaning" should use a different expression to describe their activity.

\section{B. Similarities in the Conflict of Laws}

Before moving to the jurisprudential aspect of these considerations, I want to explain one final story to depict my idea of the functioning of abstract clauses by matching it with an already studied legal phenomenon. The fiction centers, again, on the Eighth Amendment's Cruel and Unusual Punishments Clause, and draws on the distinctive modes of incorporation in the conflict of laws, by exhuming a distinction which is generally known only within the Italian scholarship.

Imagine that the Adopters of the Eighth Amendment, while transplanting the 1689 Bill of Right's formula into the U.S. Constitution, had asked themselves: What do we even mean by "cruel and unusual

255. See supra Part II.

256. Baude, supra note 5, at 2352.

257. Lawson, supra note 21 , at 1458 .

258. See also James E. Fleming, Are We All Originalists Now? I Hope Not!, 91 TEX. L. REV. $1785,1787-88$ (2013) ("If we define originalism inclusively enough, we might say that we evidently are all originalists now . . . . But if we define originalism so inclusively . . it may not be very useful to say that we are all originalists now. We may obscure our differences more than elucidate common ground. For we would persist in most of our theoretical disagreements - it is just that we would say that the disagreements are among varieties of so-called originalism"). 259. Id. 
punishments?" Instead of debating the concept, they entrust a specific Council (let us call it the "Linnaeus Council"260) with the duty of defining a vast number of punishments to be held cruel and unusual. It bears emphasizing that the list is not intended to be all-inclusive, it is merely a "gallery" of commonly viable or otherwise "cruel and unusual punishments."

The Linnaeus Council draws up the long list of viable and forbidden penalties and sends it back to the constitutional legislature. The Amenders explicitly sanction the list by adding to the Eighth Amendment the ensuing words: "[nor cruel and unusual punishments be inflected], as defined in the list adopted by the Linnaeus Council." The Amenders are explicitly referring to the list the Linnaeus Council published in 1791.

After a long period of time, harsh criticisms are addressed to the Council, demanding it update the list for the purpose of making it more decent and humane. Some old punishments should now be considered cruel and unusual, protestors claim. Though more unlikely, the opposite might apply too, so that people demand the introduction of punishments once held cruel and unusual. ${ }^{261}$ Pressed by violent social unrest, the Council yields to the requests and amends the list. Citizens cheer at the news, as courts begin enforcing the updated list.

The problem is, the original Adopters never intended to empower the Council with any amending capacity. They simply commissioned one list and proclaimed it to be law. Instead, the people and the Council interpreted the constitutional reference as to "whatever list were to be adopted by the Linnaeus Council." By deploying the Italian conflict of laws terminology, a "rinvio materiale" (material renvoi) is misconstrued as a "rinvio formale" (formal renvoi). ${ }^{262}$ Instead of pointing at a foreign legal

260. The fictional name is inspired by the great Swedish taxonomist Carl Linnaeus (17071778). See generally Isabelle Charmantier, Carl Linnaeus and the Visual Representation of Nature, 41 HisT. STUD. NAT. SCI. 365 (2011).

261. In Italy, e.g., the death penalty was outlawed by the 1889 Criminal Code, but it was subsequently re-introduced under Fascism. See PAUl GARNFINKEL, CRIMINAL LAW IN LIBERAL AND FASCIST ITALY 417 (2016).

262. Roughly speaking, we have a material renvoi when the domestic law regulates some internal case by applying some specific law of another legal system (e.g., a foreign statute), thus incorporating it as internal law (as though, i.e., the statute were carbon copied and enacted into domestic law). We have instead a formal renvoi when the domestic law refers to some specific source of the law in external legal systems. It bears emphasizing that the prima facie object of reference might be the same (e.g., a particular foreign statute), the difference being that in the case of the material renvoi any alterations in the referred legal document by its original (foreign) adopter (e.g., a foreign legislature) would not result in any change to its application in the domestic law that made reference to it. Conversely, in the case of a formal renvoi the object of the reference is not limited to the referred law (i.e., the statute per se) but also covers every possible amendment thereof: It is, precisely, a renvoi to the source that originally enacted the foreign statute. 
document and enforcing it - as if it were carbon copied and enacted qua internal law - the material renvoi legitimizes the document's author as legal source (i.e., here, the Linnaeus Council). The renvoi's reference shifts from one specific text created in another normative system to the authority that made it up, so that every authority's subsequent change has to be given efficacy. ${ }^{263}$ A typical example of material renvoi can be seen in the functioning of the Assimilative Crimes Act in the U.S. Code. ${ }^{264}$

Mutatis mutandis, a similar phenomenon can be observed in the case of the historical Cruel and Unusual Punishments Clause. Here, of course, there is no Linnaeus Council nor any tangible list of forbidden punishments. The set of prohibited punishments is made up, instead, of all

The distinction has some momentum. Italian scholars, e.g., have questioned the nature of the statute regulating the conflict of laws. See Legge 31 maggio 1995, n.218, G.U. Jun. 3, 1995, n.128 (It.). If it were to be construed as a material renvoi, every subsequent amendment of foreign sources of law would have no impact as to its application in the Italian legal system, as the reference would remain the foreign law at the time of the Italian statute (i.e., May 1995). On the opposite, it if were construed - as it is - as a formal renvoi, every modification to the foreign sources in their original system would also modify the object of reference for application of the foreign law in the domestic system. The problem can be glimpsed in the enforcement of the decisions of the Roman Rota regarding Catholic marriages. See, e.g., Roberto Giovagnoli, SEPARAZione E Divorzio 380-81 (2009) (discussing the issue and the Supreme Court of Cassation's decision to qualify the renvoi as a formal one).

Distinctions of the ways foreign law become legally relevant in the domestic legal system are generally unknown outside the Italian legal scholarship and have been criticized as "sterile," although they had some momentum for Kelsen: "[m]ost writers in other countries regard these doctrines as sterile, and even in Italy opposition to them is increasing. Nevertheless, they were taken up by Hans Kelsen in order to explain the application of foreign law within the framework of his theory according to which the law of each state is a closed system derived from a Grundnorm." Gerhard Kegel, Fundamental Approaches, in 3 INTERNATIONAL ENCYCLOPEDIA OF COMPARATIVE LAW ch. $3, \S 12$, at 11-12 (Kurt Lipstein ed.,1986).

263. I am assuming that the Linnaeus Council is an external source of law with regard to the U.S. legal system. If we are to avoid the question of whether a private institution's rules are internal or external to domestic public law, we might simply headquarter the Linnaeus Council in Uppsala, Sweden.

264. 18 U.S.C. $\S 13$. I thank Gary Lawson for directing me to this remarkable case. First enacted in 1825, the Assimilative Crimes Act was periodically re-enacted by the Congress in order to extend the states' criminal law to the areas of exclusive or concurrent federal jurisdiction ("federal enclaves") in case of crimes that were addressed by federal law. In 1948, the Congress decided to make the incorporation permanent by stating that "[w]hoever within or upon any [place of exclusive or concurrent federal jurisdiction] is guilty of any act or omission which, although not made punishable by any enactment of Congress, would be punishable if committed or omitted within the jurisdiction of the State, Territory, Possession, or District in which such place is situated, by the laws thereof in force at the time of such act or omission, shall be guilty of a like offense and subject to a like punishment." Id. Therefore, whoever violates criminal law in, e.g., a federal building, is held accountable for violating the federal criminal law that results from the incorporation of municipal criminal law, absent an autonomous federal provision. The Assimilative Crimes Act has been unsuccessfully challenged on nondelegation grounds. See United States v. Sharpnack, 355 U.S. 286, 297 (1958) (holding that " $[\mathrm{t}] \mathrm{he}$ application of the Assimilative Crimes Act to subsequently adopted state legislation, under the limitations here prescribed, is a reasonable exercise of congressional legislative power and discretion"). 
the "cruel and unusual punishments" as possibly understood by $18^{\text {th }}$ century U.S. citizens. In both cases, however, the Framers meant to prohibit a fixed set of "cruel and unusual punishments": They enforced the material renvoi to a precise domain of "cruel and unusual punishments." (The alternative entails maintaining that the Framers originally wanted to enact a formal renvoi, but that cannot be the case if we are correct in considering the Dworkinian interpretation inconsistent with the rationale of a rigid constitution, among other things). For practical reasons, nonetheless, in both cases the material renvoi has been historically construed as formal renvoi. Judges, that is, have been expected to enforce an updated version of the list. (In the fictional case there has been an aggressive demand for that, whereas in the current world the expectation has simply taken place "implicitly.") Wherefrom do we infer that the renvoi has been tacitly misconstrued? We deduce it from the very fact that the "same law new law" procedure has never taken place, nor anyone has ever demanded it.

In this perspective, it is hard to disagree with James Beck's remark that the Supreme Court acts as a "continuing constitutional convention." 265 It might be a divisive conclusion, however, whether the Court is factually performing the mentioned "democratic appreciation" 266 of majority values, or the antidemocratic enforcement of some intellectual minority's political views. ${ }^{267}$

\section{EMBRACING LEGAL REALISM}

The final question to be addressed is the practical one. If the amendment of abstract clauses does not undergo formal legal procedures, then a formalist approach to adjudication cannot account for the phenomenology of the law in this respect. And if it is the lawyer's task to master whatever happenings in the realm of law, traditional legal reasoning is not going be enough here. ${ }^{268}$

If Dworkin's model's rejection and the "same law new law" dilemma are sound, a cornerstone tenet of American Legal Realism is confirmed:

265. Berger, supra note 125 , at 3-4 (quoting JAMES M. BECK, THE CONSTITUTION OF THE UNITED STATES (1922)).

266. See supra Part II.A-B.

267. See, e.g., Lino A. Graglia, Interpreting the Constitution: Posner on Bork, 44 STAN. L. REV. 1019, 1049 (1992) (contending that "policymaking by judges...provides a means by which persons whose views were rejected in the political process may nonetheless prevail").

268. There is hardly a clearer example of traditional legal reasoning than the one expounded in SCALIA \& GARNER, supra note 151 (recollecting fifty-seven hermeneutic principles). 
legal indeterminacy. ${ }^{269}$ As Brian Leiter writes, "[legal indeterminacy] is the thesis that the Class together with relevant Background Conditions is not causally sufficient to determine only one outcome." 270 By "the Class," Leiter means the set of "legitimate legal reasons" 271 coupled with two "Background conditions": ${ }^{272}$ "(1) judges are rational, honest, competent, and error-free; and (2) the law exercises its causal influence through reasons." 273 Insofar as neither the Dworkinian nor the Borkean model explain for constitutional legal change in the case of abstract clauses, the Realists' tenet is true: In the case of abstract clauses, legal rules do not explain the behavior of judges.

How, then, should the lawyer relate to the legal change of abstract clauses, if she is to master them in court? I would imagine at least two possible lines of inquiry.

\section{A. Abstract Clauses as Indexicals}

On the one hand, it might be possible to regard the phenomenon as a linguistical conundrum. One can even recast the entire opposition between Bork's and Dworkin's originalism as a disagreement over the indexical use of notions like "cruel" and "unusual." 274

Indexicals are words like "I," "my," "that," "this," "now," "tomorrow," "actual," "present," whose reference seems to be singularly dependent on the context of utterance. ${ }^{275}$ As David Kaplan famously wrote, with indexicals "the referent is dependent on the context of use and . . . the

269. Compare Leiter, NATURALIZING JURISPRUDENCE, supra note 2, at 10-11 (distinguishing between rational, causal, global and local indeterminacy), and Lawrence B. Solum, On the Indeterminacy Crisis: Critiquing Critical Dogma, 54 U. CHI. L. REV. 462 (1987) (making a compelling case for local indeterminacy), with Mark V. Tushnet, Following the Rules Laid Down: A Critique of Interpretivism and Neutral Principles, 96 HARV. L. REV. 781 (1983) (arguing in favor of a broad account of legal indeterminacy in the "interesting" part of the law).

270. LEITER, NATURALIZING JURISPRUDENCE, supra note 2, at 9.

271. For Leiter, the Class is composed of "the legitimate sources of law," "the legitimate methods of interpreting sources of law," "the legitimate ways of characterizing the facts of a case in terms of their legal significance" and "the legitimate ways of reasoning with legal rules and legally described facts." Id. at 45 .

272. LEITER, NATURALIZING JURISPRUDENCE, supra note 2, at 9.

273. Id

274. For another case where indexicals seem relevant to constitutional interpretation see Christopher Green, "This Constitution": Constitutional Indexicals As A Basis For Textualist SemiOriginalism, 81 NOTRE DAME L. REV. 1607, 1641-67 (2009) (weighing the indexicality of Article VI).

275. The examples are taken directly from David Kaplan, Demonstratives: An Essay on the Semantics, Logic, Metaphysics, and Epistemology of Demonstratives and Other Indexicals, in THEMES From KAPLAN 481, 489 (Joseph Almog, John Perry \& Howard Wettstein eds., 1989). 
meaning of the word provides a rule which determines the referent in terms of certain aspects of the concept." ${ }^{, 276}$ In the words of David Braun,

[a]n indexical is, roughly speaking, a linguistic expression whose reference can shift from context to context. ... Many philosophers hold that indexicals have two sorts of meaning. The first sort of meaning is often called 'linguistic meaning' or 'character' .... The second sort of meaning is often called 'content'. Using this terminology, we can say that every indexical has a single unvarying character, but may vary in content from context to context. ${ }^{277}$

The reference of an indexical is context-sensitive in a way that other words are not. We all employ the word "I," even though the reference differs from person to person. Similarly, the context-sensitivity within terms like "cruel," "unusual," "punishments," appears different in character-and in reference's complexity - than in words like "thirty," "years," or "age."

It seems the very kind of problem we face in grappling with the Cruel and Unusual Clause. The definite description "cruel and unusual punishments" has only one meaning (what Kaplan calls "character" ${ }^{\text {"278) }}$ ) but refers to different objects in "different contexts." speaking, why the expression "cruel and unusual punishments" denotes different instances today than what it did in 1791. Although the meaning is the same in both contexts, once the expression has been cast by a specific agent in a specific time its reference has been attached to the sense of cruelty and usualness of some particular individuals (i.e., the Framers or the speaker at the time).

We can now translate the debate over which punishments are "cruel and unusual" ${ }^{280}$ in indexical terms. On the one hand, the expression can be commonsensically regarded as a linguistic indexical, insofar as the same words can be uttered at different moments in time and space and refer to

276. Id. at 490 .

277. David Braun, Indexicals, STAN. ENCYCLOPEDIA PHIL., (Jan. 16, 2015) https://plato.stanford.edu/archives/sum2017/entries/indexicals/ [https://perma.cc/7WCL-85MM].

278. Kaplan, supra note 275 , at 505-07.

279. I may be oversimplifying Kaplan's theory as long as I do not account for his "possible world semantics." Id. at 494. However, I think it is hardly a necessary complexity. Qua historical interpreters, we are exclusively concerned with the actual historical world in different times (i.e., today and 1791). What Kaplan warns us not to forget when recalling the "possible worlds semantics" is that indexicals are functionalized both at contexts and possible worlds. In our case, for instance, not only does the expression "cruel and unusual punishments" denote different objects for different agents at different times ("contexts"), but it could designate different objects for the same agents at the same time in two different possible worlds - the truth-value, i.e., of the indexical expressions depends also on the "circumstances of evaluation." Id. This is what goes under the name of "double-indexing." Braun, supra note 275 , at 9.

280. U.S. CONST. amend. VIII. 
quite different objects. Linguistic indexicals are theoretically suitable to a plurality of referents, but once they are uttered by a specific speaker in a specific moment their reference crystallizes in the historical utterance. This is the sense of indexicals that Bork and classic originalism should presumably agree on. We might name these proper indexicals, as no alternative account of indexicals is properly given in philosophy of language. $^{281}$

On the other hand, a Dworkinian account of this type of clauses would go one step further. ${ }^{282}$ The expression "cruel and unusual punishment" is not only a "proper indexical" (i.e., terms that can be uttered by several agents and thereby refer to very different objects) but it was meant by the Framers to be indexically used. We could speak here of "normative indexicals." Qua normative indexicals, words such as "cruel" and "unusual" are meant to be re-uttered by future interpreters and hence referred to their current times. Words are not linked to the standards of cruelty and usualness at the time of the Eighth Amendment's Framers: They refer to the different standards of every future interpreter.

For the same reasons I do not find Dworkin's account persuasive, I would shrink from interpreting abstract clauses as "normative indexicals," even though the possibility cannot be logically disposed of. It proves, however, psychologically inconsistent with the rationale of a rigid constitution. ${ }^{283}$

At the same time, to regard abstract clauses as "natural indexicals" provides little help in understanding their modification (i.e., in discovering how they get factually amended and what meanings could judges or juries attach to them in court). What is the lawyer to do with the bare acknowledgment that she is facing this particular instance of natural language? How would this renewed awareness about its semantic character help her in providing legal expertise? How would it enhance her performance in court? It appears as though the "linguistic turn" in legal scholarship does not agree with the practical purposes that mostly concern the lawyer. ${ }^{284}$

The alternative approach, conversely, requires widening the scope of legal inquiry to non-legal determinants of behavior.

281. Braun, supra note $273, \S 1.3$.

282. See supra Part I.B-II.A (describing Dworkin's account).

283. See supra Part II.B.1.

284. See infra Part V.B for the proposed notion of "legal scholar." 


\section{B. The Lawyerly Business}

Informal, "nonoriginalist" amending does not translate in haphazard amending. If we accept a commonsensical deterministic hypothesis about the world, legal rules' causal inefficacy implies that there will be other rules (i.e., non-legal rules, such as moral, psychological, social, economic ones) that determine and causally constrain the legal change of abstract clauses. ${ }^{285}$ Legal indeterminacy does not equal general indeterminacy. ${ }^{286}$ If the amending behavior that presumably takes place in the case of abstract clauses is not legal (i.e., it cannot be explained through legal reasons), then the behavior must be normatively controlled by other determinants (i.e., "non-legal reasons"). ${ }^{287}$ In other words, there is no need to give up on the idea of behavior as acting according to a rule: The acknowledgment of non-legal rules of behavior (i.e., the aforementioned "alternative normative domains") fills the causal gap. ${ }^{288}$

If we credit the hypothesis, the ongoing validity of another fundamental tenet of American legal realism - or at least, as Leiter calls it, of its "Sociological Wing"289 — is being reclaimed: that in order to grasp the functioning of some phenomena in the law (here, the amendment of abstract clauses) the lawyer cannot but draw on social sciences like sociology, anthropology, and psychology that aim at explaining the nonlegal determinants of human behavior. ${ }^{290}$

As Leiter points out,

if the Sociological Wing of Realism-Llewellyn, Moore, Oliphant, Cohen, Radin, among others - is correct, then judicial decisions are causally determined (by the relevant psycho-social facts about judges), and at the same time judicial decisions fall into predictable patterns because these psycho-social facts about judges (e.g., their professionalization experiences, their backgrounds) are not idiosyncratic, but characteristic of significant portions of the judiciary. Rather than rendering judicial decision a mystery, the

285. "[E]ven if legal reasons underdetermine the decision, there still may be non-legal reasons (e.g. reasons of morality or policy) that do justify a unique decision . . . ." LEITER, NATURALIZING JURISPRUDENCE, supra note 2, at 40.

286. Id. at $10-11$.

287. Id. at 24

288. Id. at 40

289. Id. at $15,28-29$.

290. "[T] $]$ he idea is that judges instantiate general characteristics, rather than idiosyncratic ones. What these general characteristics are may be illuminated by sociology, or social psychology, or anthropology." Id. at 29. 
Realists' Core Claim, to the extent it is true, shows how and why lawyers can predict what courts do. ${ }^{291}$

Legal indeterminacy solely implies that a formalistic approach cannot account for the whole functioning of legal phenomena. ${ }^{292}$ The lawyer, therefore, needs to borrow cognitive tools and instruments from other social sciences to achieve a comprehensive account of the law. ${ }^{293}$ As Leiter again writes, "the thesis at issue here [in American Legal Realism] is that ... when legal reasons do not justify only one outcome, then other psychological and sociological factors (e.g., the personality or the political ideology of the judge) must come into play to causally determine the decision." 294

But why should the jurist be concerned with these psychological and sociological factors? Could she not leave it to the psychologist or the sociologist to deal with? It all boils down to the notion of "lawyer" or "legal scholar" one retains. I would think of a "lawyer" as the individual who knows the law better than the average citizen (i.e., more broadly or more thoroughly) and that offers her expertise as a commercial good. ${ }^{295}$ If knowing the law means being able to explain its happenings in a causal fashion and being able to predict its developments, then only stretching legal inquiry beyond formal rules might give the lawyer proper tools to achieve what she is striving for (i.e., causal explanations of legal phenomena and predictions of what courts will to).

This would enable her, we might say, to become who she is. ${ }^{296}$

291. Id

292. I subscribe here to the realists' thesis of "Local Rational Indeterminacy," as Leiter calls it, to juxtapose it with the C.L.S. writers' "Global Rational Indeterminacy." See id. at 11-12. "Local Rational Indeterminacy" suggests that the application of the law is indeterminate-i.e., not determinate by legal reasons - only in certain instances: For the realists, those are the cases that are actually litigated. Global Indeterminists, conversely, maintain the law to be always indeterminate. See id. at 19-20.

293. "The social sciences then-conceived "positivistically" (that is, on the model of the natural sciences) - were the tool for performing this crucial task. By approaching law like a behaviorist psychologist, an anthropologist, or an empirical sociologist, the Realists hoped to discover the real patterns of judicial decision-making, thus providing information of practical value to lawyers." $I d$. at 90.

294. Id. at 10

295. It bears noting that I am merely holding to the Legal Realism's traditional account of the lawyerly business as the one dealing in "actual specific past decisions, and guesses as to actual specific future decisions." FRANK, supra note 12, at 51.

296. "[H]ow one becomes what one is." FrIedrich Nietzsche, ECCE Homo: How ONE BeCOMES WhAT ONE Is \& THE ANTICHRIST: A CuRSE ON CHRISTIANITY 36 (Thomas Wayne trans., 2004). 


\section{CONCLUSION}

This Article illustrates the difficulty of describing the legal change of the U.S. Constitution's abstract clauses in originalist terms and, in doing so, stresses the ongoing necessity for the kind of legal inquiry American legal realism has historically advocated. In that both the Dworkinian and Borkean originalist accounts prove unable to satisfactorily explain the legal change of abstract clauses, constitutional law is nonoriginalist at least regarding this area of the law. The conclusion, however, is not a blanket refutation of formalism and originalism. More modestly, it means acknowledging that the human value that often renders originalism a good descriptive account of legal phenomena-namely, the certainty value within the formalism it encapsulates - is in competition with othersnamely, the desirability of the outcomes. Whenever the latter prevails on the former, originalism and formalism turn out descriptively unsound.

But if it is the lawyer's job to "know her way around" in those areas of the law that do not respond to formal legal reasoning, only disciplines concerned with other domains of normativity (psychology, sociology, anthropology, economics, etc.) are going to help her in carrying out her duty. Conversely, it is hard to expect any help from analytic philosophy, although abstract clauses resemble strikingly the function of the linguistic expressions analytic philosophy dubs "indexicals."

However, both the indeterminacy of the law and the necessity to address it through different social sciences were already clear fundamental tenets in the American legal realism. Hopefully, the Article should reaffirm the ongoing relevance of the realists' insights for constitutional law. 